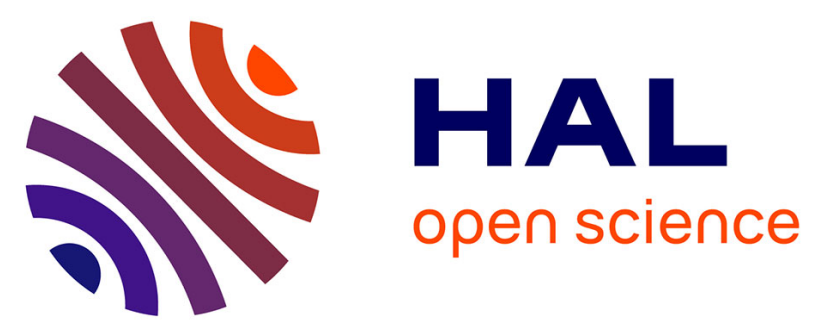

\title{
Metabolomics approach based on LC-HRMS for the fast screening of iron(II)-chelating peptides in protein hydrolysates
}

Cédric Paris, Katalin Selmeczi, Bruno Ebel, Loic Stefan, Gizella Csire, Céline Cakir-Kiefer, Stéphane Desobry, Laetitia Canabady-Rochelle, Patrick Chaimbault

\section{To cite this version:}

Cédric Paris, Katalin Selmeczi, Bruno Ebel, Loic Stefan, Gizella Csire, et al.. Metabolomics approach based on LC-HRMS for the fast screening of iron(II)-chelating peptides in protein hydrolysates. Analytical and Bioanalytical Chemistry, 2021, 413, pp.315 - 329. 10.1007/s00216-020-03037-1 . hal03447732

\section{HAL Id: hal-03447732 \\ https://hal.science/hal-03447732}

Submitted on 26 Nov 2021

HAL is a multi-disciplinary open access archive for the deposit and dissemination of scientific research documents, whether they are published or not. The documents may come from teaching and research institutions in France or abroad, or from public or private research centers.
L'archive ouverte pluridisciplinaire $\mathbf{H A L}$, est destinée au dépôt et à la diffusion de documents scientifiques de niveau recherche, publiés ou non, émanant des établissements d'enseignement et de recherche français ou étrangers, des laboratoires publics ou privés. 


\section{Query Details}

Back to Main Page

1. The article title has been modified. Please check if correct.

It's OK with the change.

2. Please check if the affiliation section is presented correctly. Also, please check if all the authors' telecommunications data are correctly captured or indicated.

I's OK like that.

3. Please check if section headings are assigned to appropriate levels.

It's OK.

4. Several modifications were made in the body. Please check if the modifications are correct and retained the intended meaning.

It's OK.

5. Please check if all figure captions are presented correctly. All figures in docs manuscript ( abc-01728-2020-File001.docx) were followed. Please confirm if correct.

It's OK

6. Please check the sentence "A short separation program was...." for clarity and correctness.

Thank you, the word "for" was missing, the correct sentence is:

"A short separation program was developed for simple samples analysis..."

7. Figures 2-3,6, Graphical Abstract contains poor quality and small text inside the artwork. Please do not re-use the file that we have rejected or attempt to increase its resolution and resave. It is originally poor, therefore, increasing the resolution will not solve the quality problem. We suggest that you provide us the original format. We prefer replacement figures containing vector/editable objects rather than embedded images. Preferred file formats are eps, ai, tiff and pdf.

I understand, I will attach you all my original files concerning the Figures:

- Fig 2: 5 pdf files and a TIF file ( 2 files for the $\beta A H$ [full and zoom]; 2 files for the RKR [full and zoom]; 2 files for the WWW [full and zoom])

- Fig 3: 2 pdf files for the MS spectra (one for GGH and one for DAH)

2 pdf files for the chromatograms (one for GGH and one for DAH) 
- Fig 4: 1 excel file concerning the RAC according to the iron/peptide ratio (previously sent)

- Fig 5: 2 pdf files (one for the synthetic hydrolysate, one for the casein hydrolysate)

- Fig 6: I am sorry but I am afraid that I cannot give you a better version than the one transmitted previously (PPT format)

8. Please check if Tables 1,2 , and 3 are presented correctly.

The tables are $\mathrm{OK}$.

9. Figures 4 please confirm if captured correctly.

It's OK.

10. Figures 4-5 contains poor quality of text inside the artwork. Please do not re-use the file that we have rejected or attempt to increase its resolution and re-save. It is originally poor, therefore, increasing the resolution will not solve the quality problem. We suggest that you provide us the original format. We prefer replacement figures containing vector/editable objects rather than embedded images. Preferred file formats are eps, ai, tiff and pdf.

I will attach the original versions pour Fig 4 and Fig 5:

- Fig 4: excel format (previously sent)

- Fig 5: 2 new pdf files

Metabolomics approach based on LC-HRMS for the fast

Paris C. et al.

screening of iron(II)-chelating peptides in protein hydrolysates

\section{Paper in Forefront}

\section{Metabolomics approach based on LC- HRMS for the fast screening of iron(II)-chelating peptides in protein hydrolysates}

AQ1

Cédric Paris, 1,2 
Email cedric.paris@univ-lorraine.fr

Cédric Paris is Research Engineer at the University of Lorraine (France). He is the manager of the Platform of Structural and Metabolomics Analyses (PASM) dedicated to the analysis of biomolecules in the fields of food sciences, agronomy, plant sciences, soils, and environment. His Ph. D. thesis (2017-2020) focused on the development of non-targeted methods for screening iron-chelating peptides by mass spectrometry.

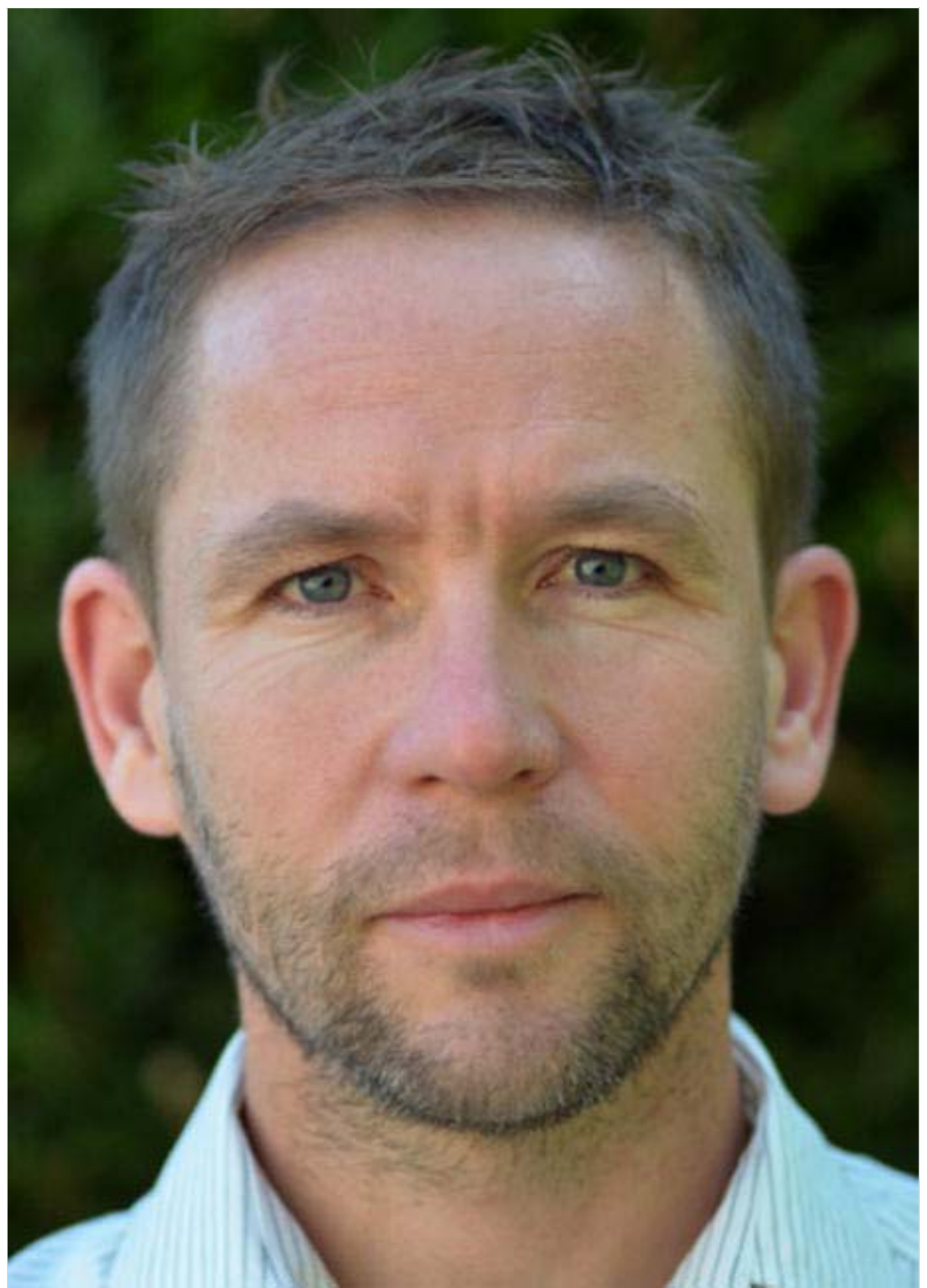


Katalin Selmeczi, 3

Katalin Selmeczi works as a teacher-researcher at the Lorrain Laboratory of Molecular Chemistry (L2CM) of the University of Lorraine (Nancy, France). Her current research interests are biological coordination chemistry, transition metal complexes of peptides and macrocyclic compounds, applications of coordination chemistry in enzyme-active site mimetics and medicine.

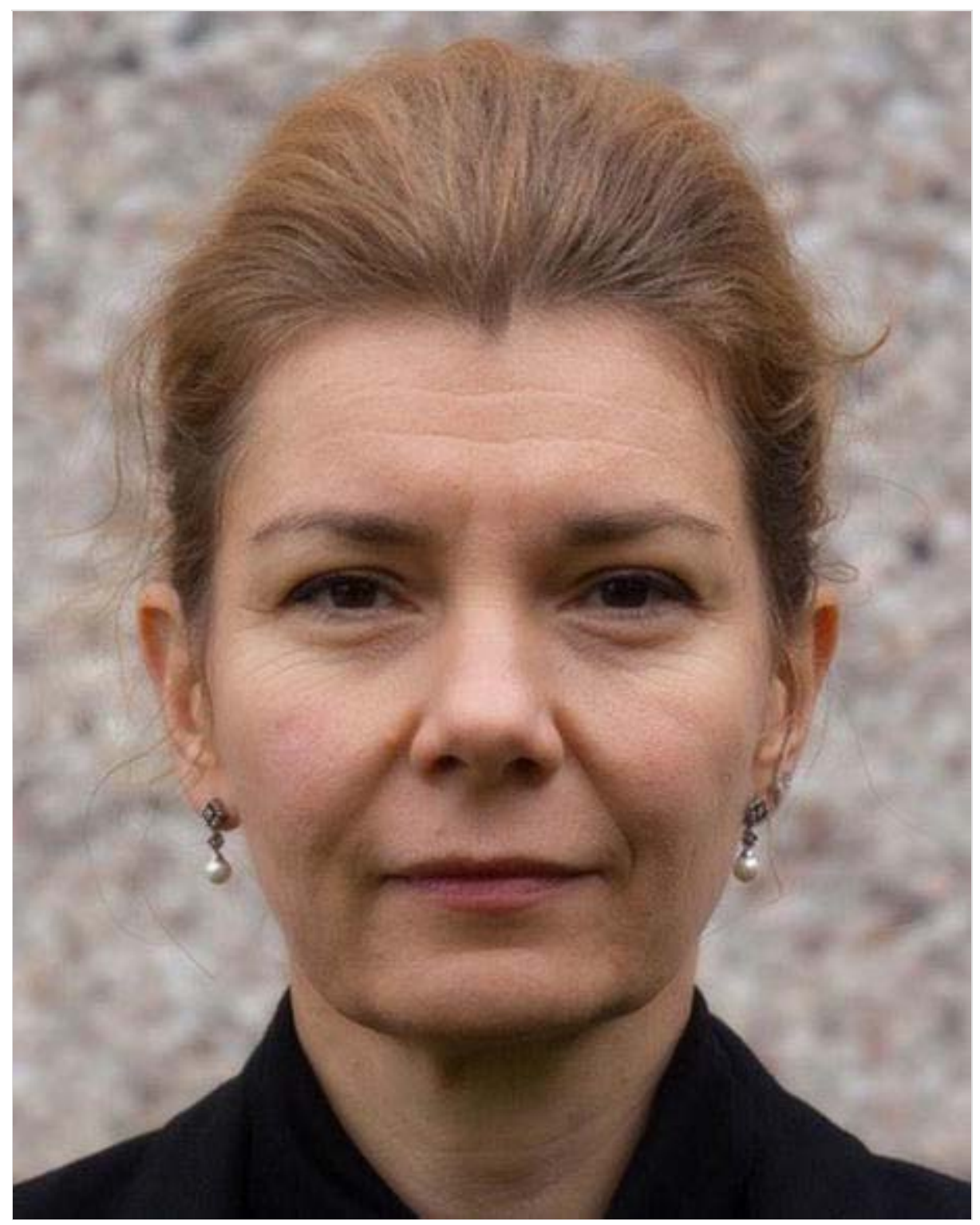

Bruno Ebel, 4

Bruno Ebel is Associate Professor at Reactions and Chemical Engineering Laboratory (LRGP), at the University of Lorraine (Nancy, 
France). He works specifically on multivariate data analysis in biotechnology.

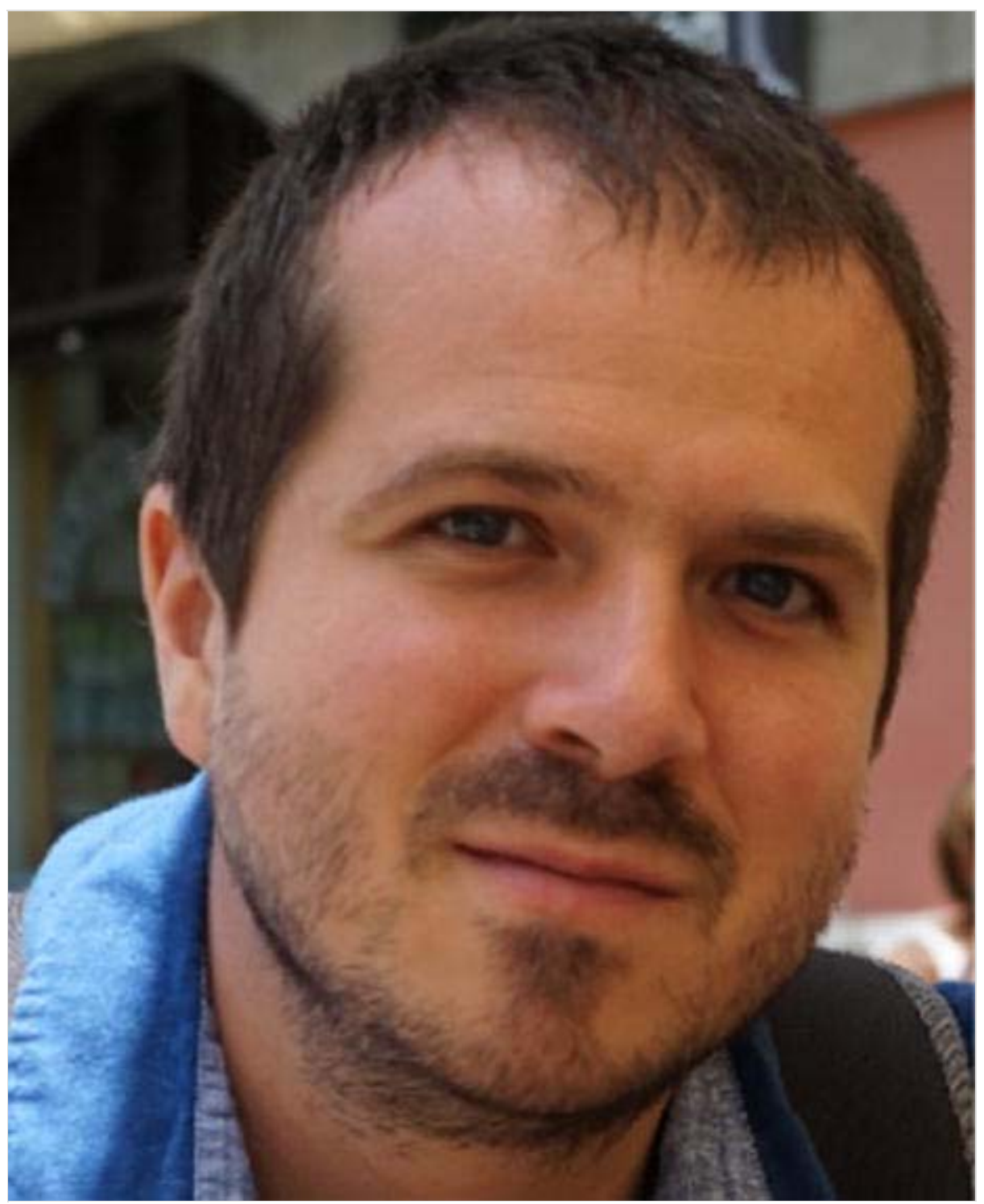

Loic Stefan, 5

Loic Stefan is a CNRS researcher working at the Laboratory of Macromolecular Physical Chemistry (Nancy, France). He specialized in biomimetic self-assembly processes based on DNA and peptide derivatives, from fundamental research and molecular design to applications. His current researches focus on the use of peptides and peptide derivatives to develop both innovative soft materials (gels) and antioxidant metal-binding peptides. 


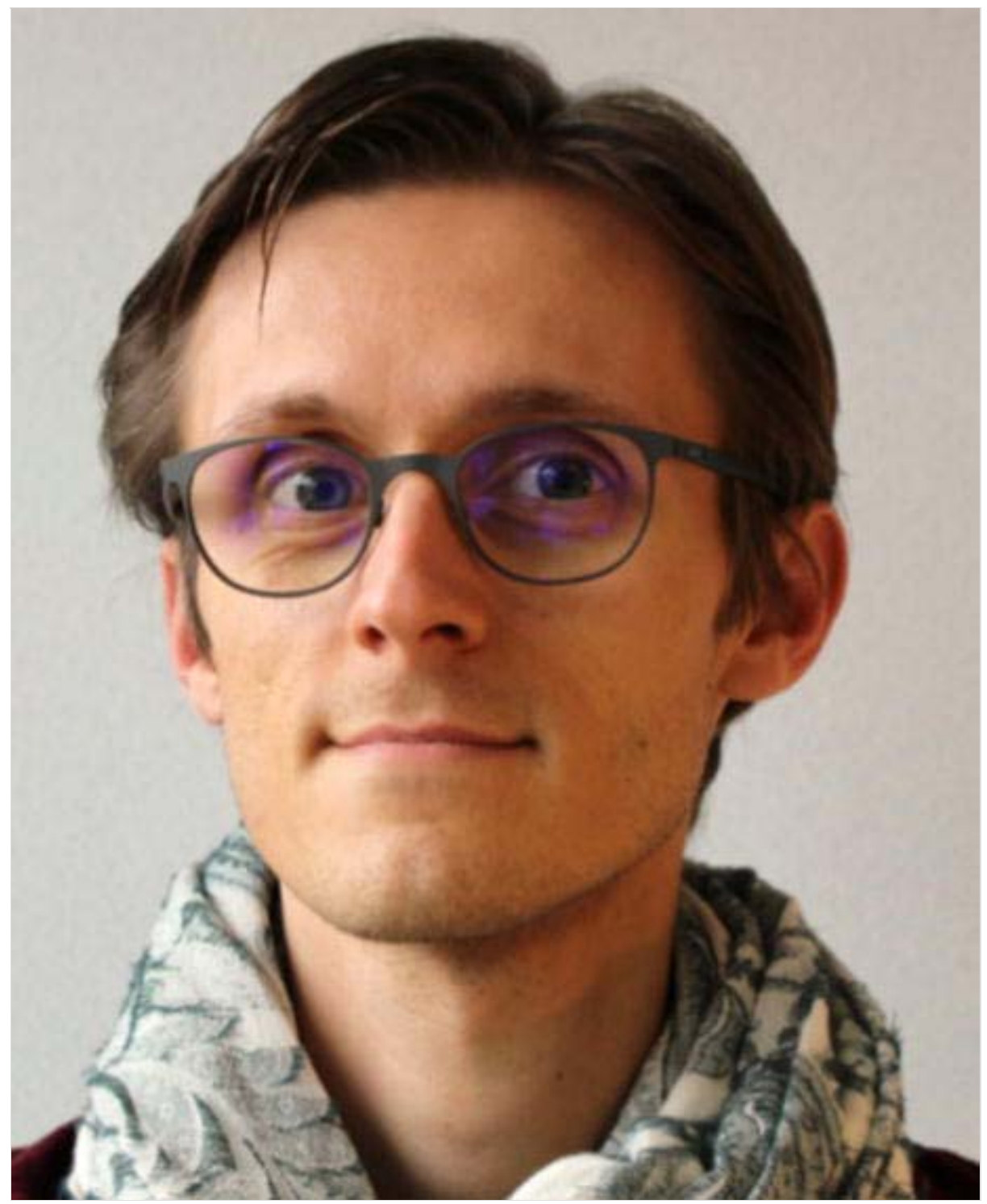

Gizella Csire, 3,5

Gizella Csire is currently working at the University of Lorraine (Nancy, France) in the L2CM laboratory as a postdoctoral fellow. She has experience in the special field of analytical chemistry: equilibrium studies and structure analysis of metal-peptide complexes. 


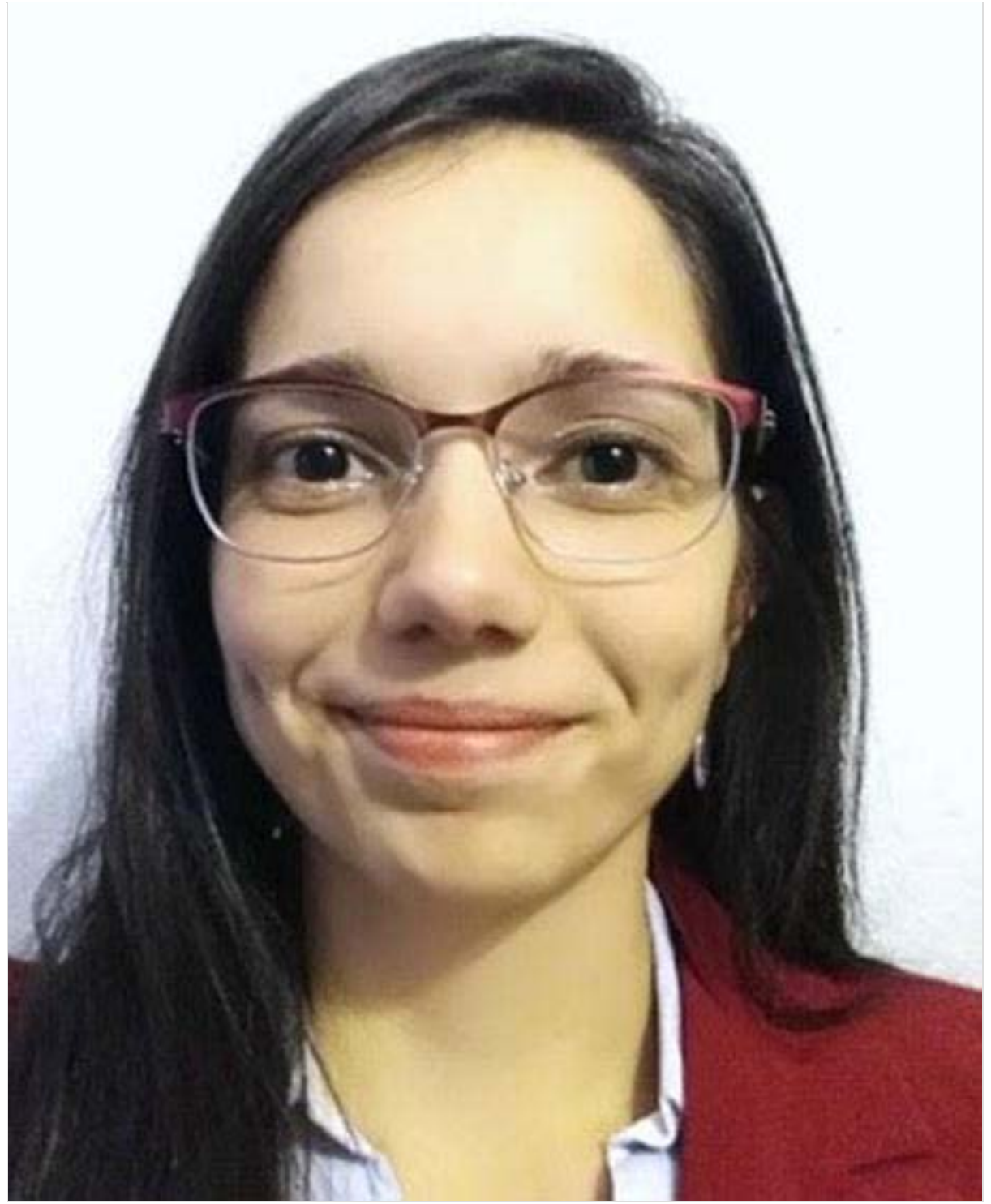

Céline Cakir-Kiefer, 6

Céline Cakir-Kiefer is Assistant Professor in Food Biochemistry at the University of Lorraine (Nancy, France) and in charge of the Master in Nutrition and Food Sciences. His field of research focuses on bioactive peptides and more particularly the interactions between metals and milk proteins. The objective is to study the site of interaction of metallic trace elements. 


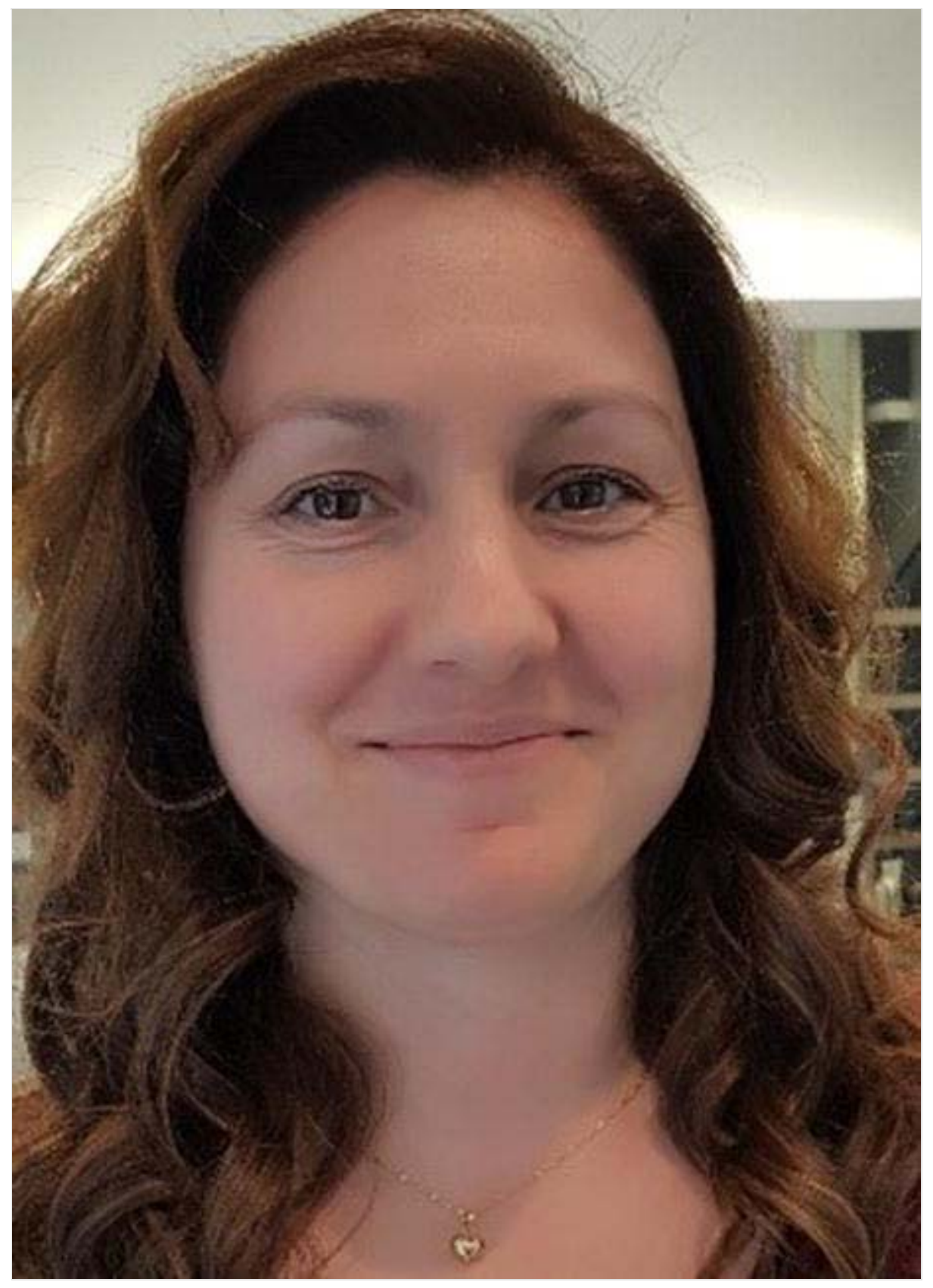

Stéphane Desobry, 1

Stéphane Desobry is Full Professor at the University of Lorraine (Nancy, France). He is coordinator of the "Impact Biomolecules" project that brings together 140 researchers from 17 laboratories. 


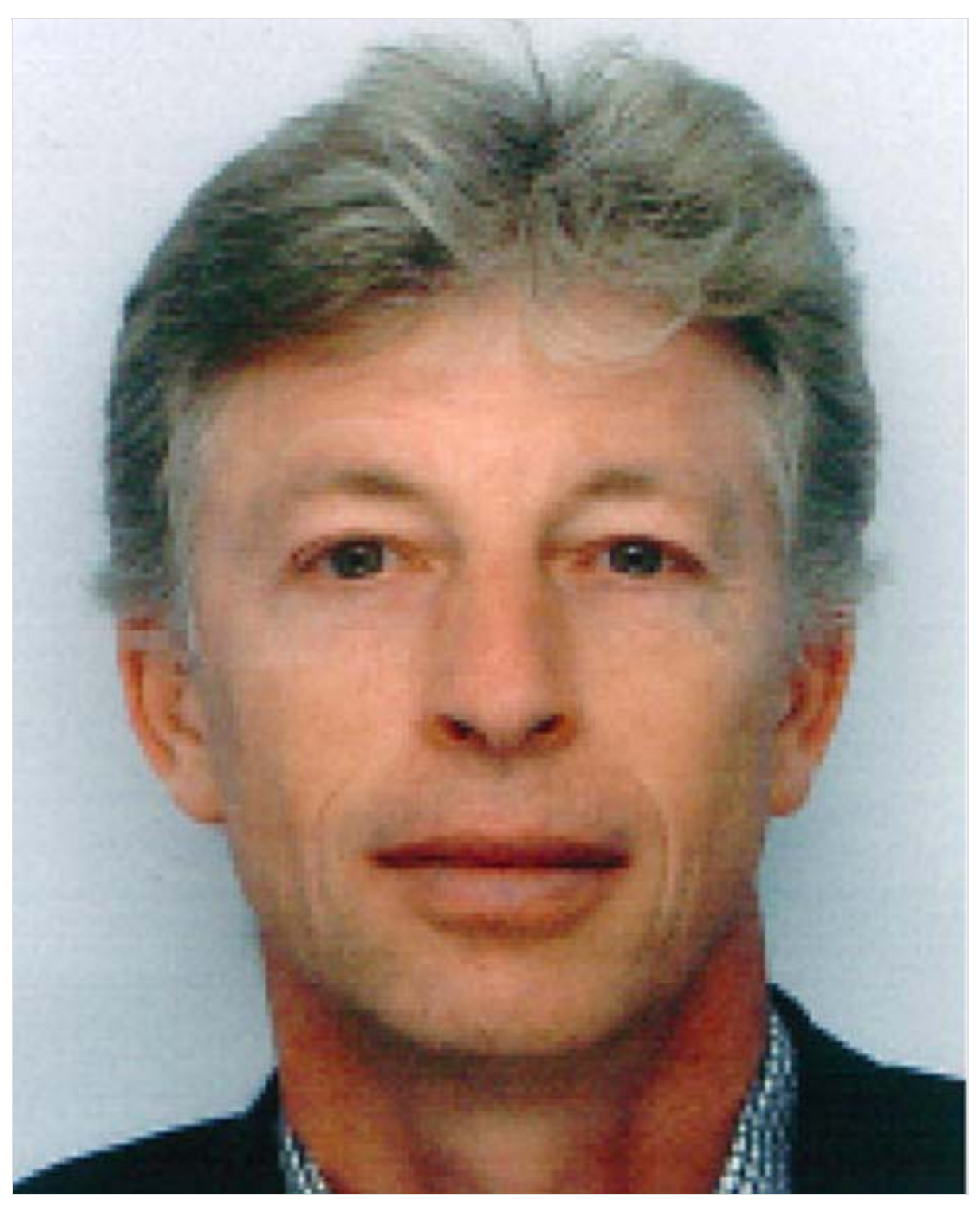

Laetitia Canabady-Rochelle, $4 \square$

Email laetitia.canabady-rochelle@univ-lorraine.fr

Laetitia Canabady-Rochelle is CNRS Research Scientist (Bioprocesses-Biomolecules axis, LRGP) at the University of Lorraine (Nancy, France). Her researches focus on production, screening, and separation of metal-chelating peptides (MCP) in hydrolysates for various applications. Representative of the MCP work package (LUE IMPACT Biomolecules project), she is the co-chairwoman of the 1 st international conference on "Metal-Binding Peptides: Methodologies \& Application", Nancy, France, July 2021. 


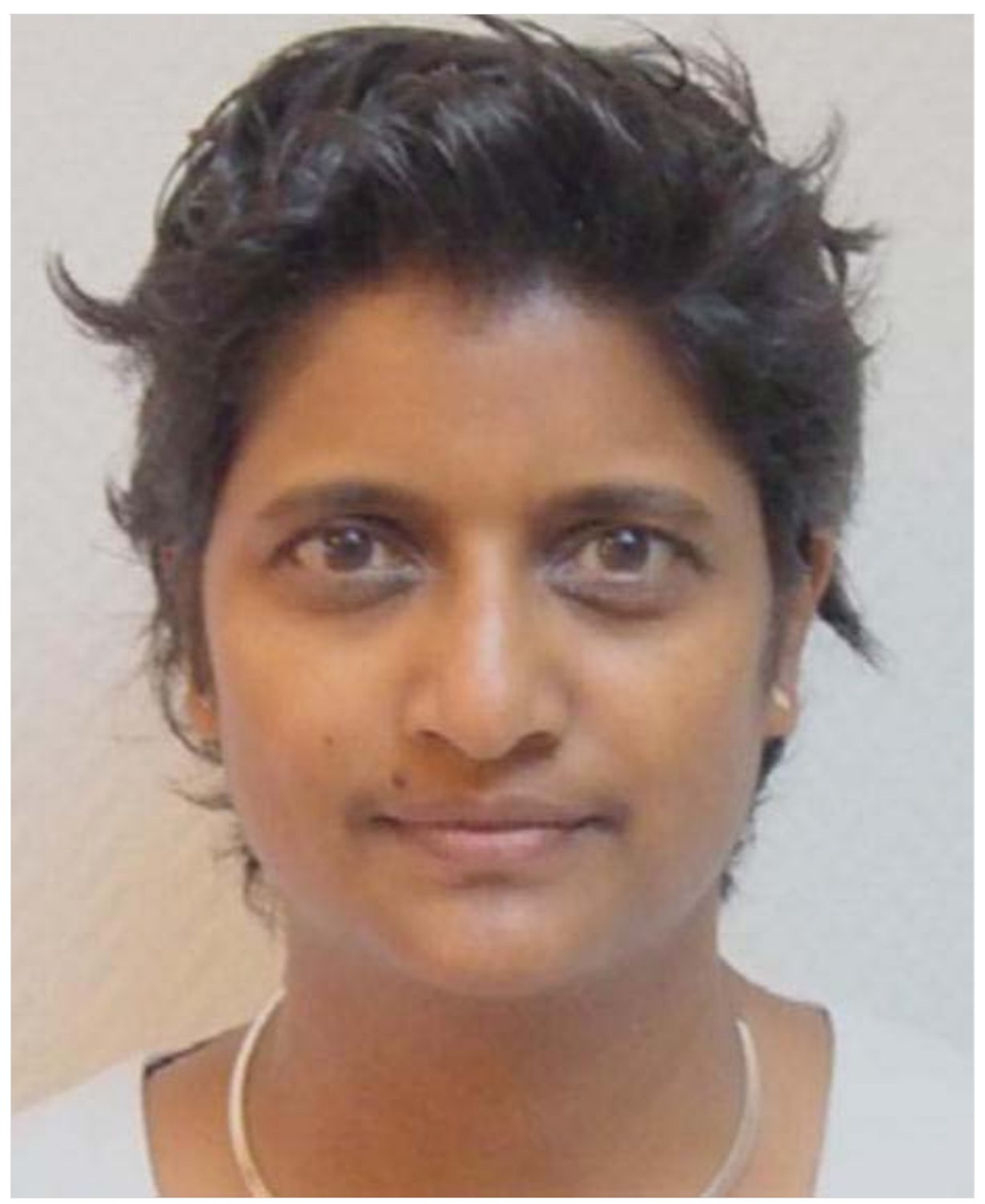

Patrick Chaimbault, 7

Patrick Chaimbault started an academic career in 2002 after holding positions of laboratory manager in the pharmaceutical industry. He was promoted to Full Professor at the University of Lorraine in November 2008 in which he teaches and conducts researches in analytical chemistry (Metz, France). His field of expertise is centered on the coupling of separative techniques with mass spectrometry applied to the characterization of complex biological samples. 


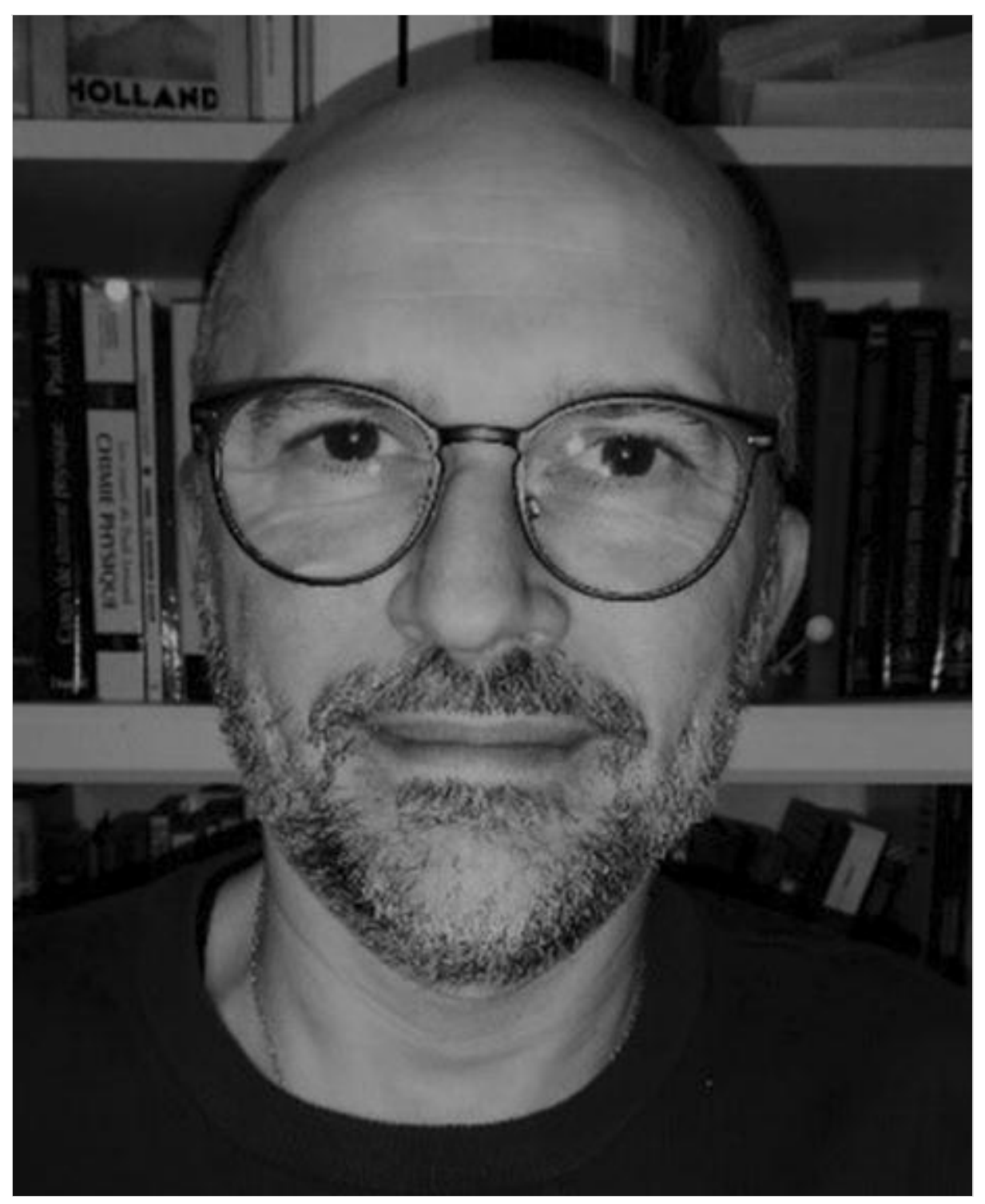

1 Université de Lorraine, LIBic AQ2 , 54000 Nancy, France

2 Université de Lorraine, PASM, 54000 Nancy, France

3 Université de Lorraine, CNRS, L2CM, 54000 Nancy, France

4 Université de Lorraine, CNRS, LRGP, 54000 Nancy, France

5 Université de Lorraine, CNRS, LCPM, 54000 Nancy, France

6 Université de Lorraine, INRAE, URAFPA, 54000 Nancy, France

7 Université de Lorraine, LCP-A2MC, 57000 Metz, France 
Received: 5 September 2020 / Accepted: 28 October 2020

\section{Abstract}

Production of iron-chelating peptides from protein hydrolysates requires robust and adequate screening methods to optimize their purification and subsequently valorize their potential antioxidant properties. An original methodology was developed for direct and sensitive screening of iron(II)-chelating peptides based on ion-pair reverse phase liquid chromatography (IP-RPLC) coupled to high-resolution mass spectrometry (HRMS). Peptide mixture was first added to iron(II) solution to form iron(II)-peptide complexes. Then IP-RPLC-HRMS analysis was conducted on this iron-peptide mixture and on the iron-free peptide solution for comparative mass spectra analysis. This protocol, initially applied to a range of low molecular weight standard peptides, allowed detection of $\left[(\text { Peptide-H })+{ }^{56} \mathrm{Fe}^{\mathrm{II}}\right]^{+}$complex ion for iron(II)chelating peptides (GGH, EAH, DAH, $\beta A H, D M H, D T H, D S H) . G G H$ was added in complex peptide mixtures and targeted analysis of [ $(\mathrm{GGH}-$ $\left.\mathrm{H})+{ }^{56} \mathrm{Fe}^{\mathrm{II}}\right]^{+}$complex showed a limit of detection (LOD) below $0.77 \mathrm{mg} \mathrm{L}^{-1}$ of GGH. This protocol was finally tested in combination with metabolomics software and additional digital processing for nontargeted search for iron(II)-chelating peptides. Applicability of this new screening methodology has been validated by detection of GGH as iron(II)-chelating peptide when added at $0.77 \mathrm{mg} \mathrm{L}^{-1}$ in casein hydrolysate.

\section{Graphical abstract}




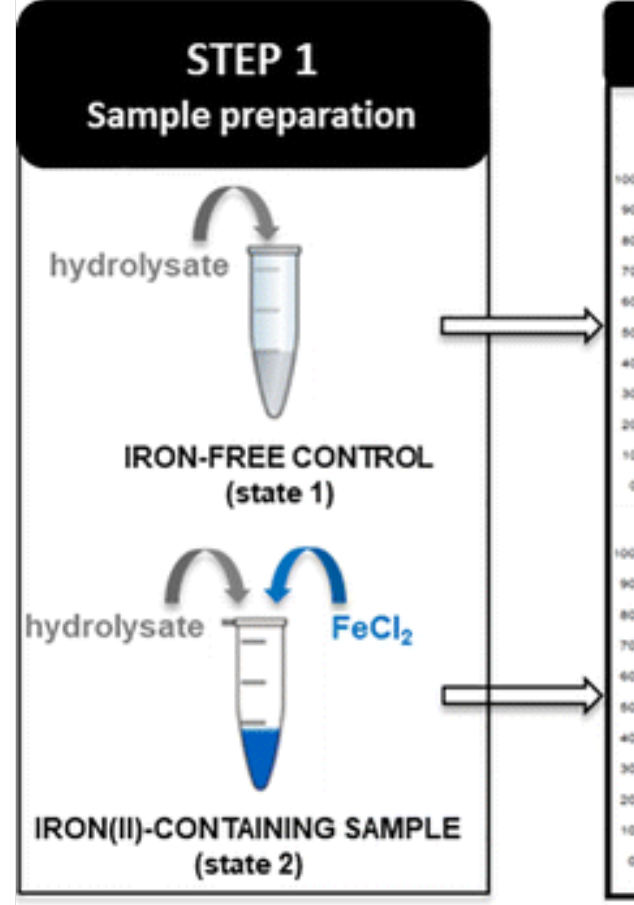

\section{STEP 2 Data acquisition}

IP-RPLC-ESI-HRMS HRMS SPECTRA COLLEC

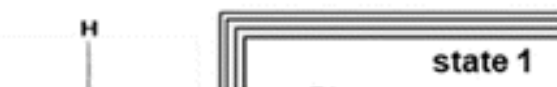

Iron-free control
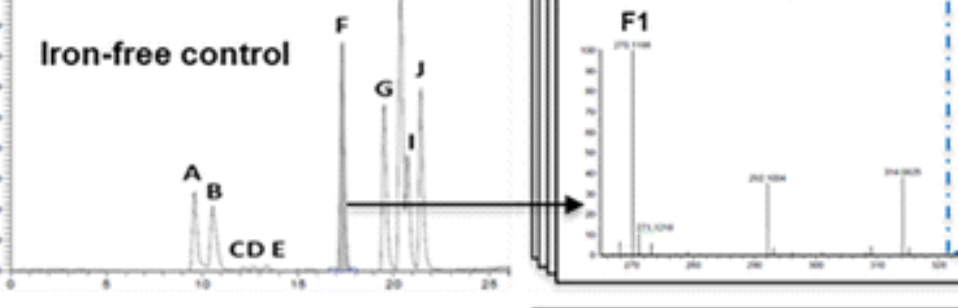

F1

With iron(II)

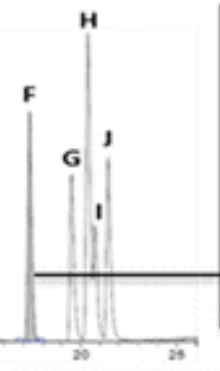

state 2

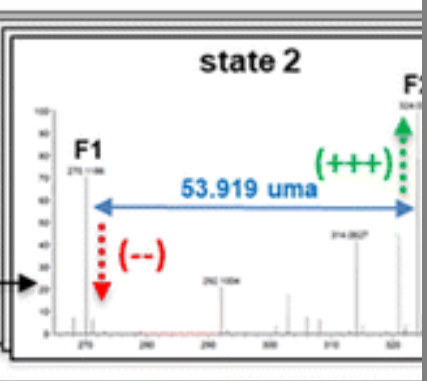

\section{Keywords}

Iron (II)

Metal-chelating peptides

Direct screening

Online LC-MS method

Protein hydrolysates

Supplementary Information

The online version contains supplementary material available at https://doi.org/10.1007/s00216-020-03037-1.

\section{Introduction}

\section{AQ3}

Study and follow-up of reactive oxygen species (ROS) level in living organisms is currently a hot topic. ROS are playing important roles as regulatory agents. For example, homeostasis of nitric oxide pool in case of cardiovascular diseases is essential to fight against oxidative stress and inflammation. However, it is common knowledge that ROS excess induces 
oxidative damages leading to many pathologies such as cancers or neurodegenerative diseases.

AQ4

Among the mechanisms leading to ROS in cells, iron(II) is well known to catalyze their production including highly reactive free radical $\mathrm{HO}^{\bullet}$ through the Fenton reaction (1). In case of iron overload, uncontrolled increase in pro-oxidant iron(II) level in intracellular labile iron pool (LIP) causes oxidative stress $[1,2]$.

Sequestration of transition metals [3], and more particularly iron(II), by chelating peptides is one of the promising ways to limit ROS proliferation in cells. Indeed, these peptides are able to slow down ROS production by inhibiting redox activity of metal ions [4]. Thus, antioxidant peptides appear of great interest for applications in the field of pathologies related to oxidative stress [5]. Enzymatic protein hydrolysates are widely used since the last two decades for production of bioactive peptides with healthrelated functional properties [6]. The high complexity of these kinds of hydrolysates containing up to hundreds of peptides represents a challenge for both identification and purification of bioactive peptides usually present at low concentration [7].

Bioinformatics-driven approach recently emerged for prediction of bioactive peptide sequences; however, it currently suffers from a lack of knowledge concerning the structure-activity relationship [8].

Consequently, usual characterization of bioactive peptides is mainly based on a tedious and time-consuming empirical approach comprising repeated cycles of activity-guided steps of purification until their final identification by mass spectrometry (Fig. 1a) [7, 8].

Fig. 1

Overview of screening methods for metal-chelating peptides in protein hydrolysates. a The usual multi-step empirical protocol, b the three-step protocol based on immobilized metal affinity chromatography (IMAC) followed by an offline MS step, and c the proposed single-step direct protocol based on LC-MS 


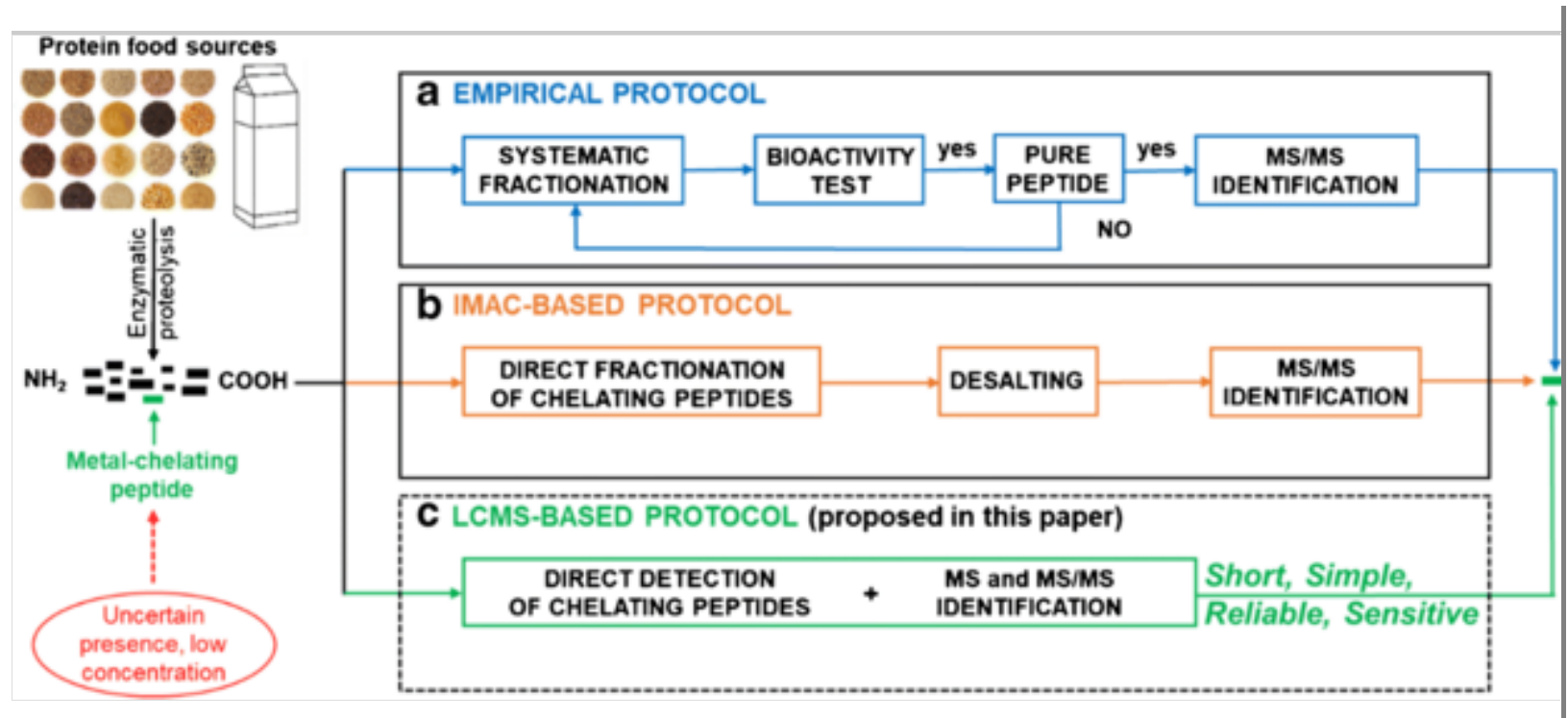

Several alternatives have been considered to reveal and purify antioxidant compounds in complex mixtures. In particular, online methods combining separative step with free radical scavenging test have been implemented to highlight (poly)phenolic compounds and peptides exhibiting antioxidant properties $[9,10,11,12]$. Nevertheless, this methodology requires high chromatographic resolutions to avoid co-elution for an accurate characterization by mass spectrometry in a second step.

Direct screenings of metal chelators can be achieved using their ability to complex metal ions. Immobilized metal ion affinity chromatography (IMAC), based on interaction between ligands in mobile phase and immobilized metal ion [13], has often been used to fractionate peptides and improve gastrointestinal absorption of many elements $[14,15,16,17$, 18]. Thus, copper(II) [18, 19, 20] or iron(II)-chelating peptides [21, 22] have been purified by this way and, subsequently, identified by LCMS/MS. However, use of non-volatile mobile phases in standard IMAC necessarily imposes an additional desalting step before MS identification (Fig. 1b). Moreover, the number of free chelating sites remaining for peptide complexation after the immobilization of the transition metal ion on stationary phase (i.e., 2 or 3 free sites depending on the commonly used chelating agents) [23] constitutes a potential bias to confirm peptides' chelating ability. Electrospray mass spectrometry (ESI-MS) has been largely reported for studying many metal-organic ligand complexes, not only for their speciation but also to access their stoichiometry [24, 25]. 
The ESI-MS technique is also widely used to study interactions between small synthetic peptides and metal ions and validate the composition of complexes in solution [26, 27, 28]. Another work described identification of iron(II)-peptide complexes by ESI-MS after their isolation by IMAC [21]. However, all of the approaches described above imply multi-step and time-consuming protocols and none of them allows a direct screening of iron(II)-chelating peptides.

The aim of the present work was to develop a rapid, simple, and sensitive LC-MS protocol for direct screening of potential iron(II)-chelating antioxidant peptides in complex hydrolysates (Fig. 1c). This protocol is based on a differential LC-HRMS analysis between a protein hydrolysate (control) and the same hydrolysate after incubation with iron(II). This new approach should drastically draw down total duration for highlighting relevant iron(II)-chelating peptides compared to the empirical approach (1 month or more: see Fig. 1a) and to the protocol based on IMAC (1 week or more: see Fig. 1b).

Development was carried out on a fairly large panel of standard peptides, exhibiting sizes of 2 to 10 amino acids and varied sequences. However, the choice of model peptides was intentionally oriented along three criteria. First, we selected a large part of peptides with at least one histidine residue because this specific amino acid is well known for its ability to complex many transition metals. Second, since the main application of antioxidant chelating peptides is their use as oral drugs against oxidative stress, we focused more particularly on di- and tripeptides believed to be bioavailable [29]. Third, peptides containing a motif with three successive acidic residues (D, E) — well known for chelating iron(III) - were also selected to demonstrate the potential specificity of complexation with iron(II).

\section{Experimental section}

\section{Chemicals and reagents}

Majority of synthetic peptides used were purchased from GeneCust (Boynes, France): GGH, NCS, CAH, DAH, HGH, IKP, EAH, DSH, DDD, DTH, DED, DMH, EEE, HHH, IKW, RKR, RQR, WWW, YPISL, HHHHHH, and LLPHHADADY. Their purity degree was greater than 
95\%. The two peptides $\gamma \mathrm{ECG}$ (glutathione) and $\beta \mathrm{AH}$ (carnosine) were purchased from Sigma-Aldrich and showed a purity greater than $98 \%$. FDDDK and FDDDA standard peptides were synthetized internally with a purity degree of $98 \%$ [30]. Pure stock solutions of peptides were prepared at $10 \mathrm{~g} \mathrm{~L}^{-1}$ in water, except for WWW prepared in a 1:1 methanol/water mixture. Chromatographic eluents were prepared with LC-MS grade methanol $(\geq 99.9 \%)$, ultra-pure water, and nonafluoropentanoic acid (NFPA, 97\%).

\section{Hydrolysates}

A mixture of standard peptides assimilated to a synthetic hydrolysate was built comprising the following 13 peptides, namely $\gamma \mathrm{ECG}$, NCS, IKP, DDD, DED, EEE, HHH, IKW, RKR, RQR, YPISL, HHHHHH, and LLPHHADADY. Fifty microliters of each stock solution $\left(10 \mathrm{~g} \mathrm{~L}^{-1}\right)$ was pooled to provide a mixture at $0.77 \mathrm{~g} \mathrm{~L}^{-1}$ in each peptide. This mixture was then diluted by 10 with water to obtain synthetic hydrolysate at $0.077 \mathrm{~g} \mathrm{~L}^{-1}$ of each peptide corresponding to a total concentration of peptide equal to $1 \mathrm{~g} \mathrm{~L}^{-1}$ (Electronic Supplementary Material (ESM) Table S1).

Tryptic casein hydrolysate was prepared at a total peptide concentration of $1 \mathrm{~g} \mathrm{~L}^{-1}$. Sodium caseinate from bovine milk (Sigma-Aldrich, St. Louis, MO, USA) was solubilized at $5 \mathrm{~g} \mathrm{~L}^{-1}$ in $50 \mathrm{mM}$ sodium bicarbonate, pH 8.0. L-1-tosylamide-2-phenylethyl chloromethyl ketone-treated trypsin (EC 3.4.21.4) from bovine pancreas $\left(10,000 N_{\alpha}\right.$-benzoyl-L-arginine ethyl ester hydrochloride or BAEE units $\mathrm{mg}^{-1}$ enzyme; Sigma-Aldrich) was added at $50 \mu \mathrm{g} \mathrm{mL}^{-1}$. After hydrolysis at $37^{\circ} \mathrm{C}$ under gentle shaking for $2 \mathrm{~h}$, the reaction was stopped by lowering the $\mathrm{pH}$ to around 2.0 with trifluoroacetic acid. Salt-free hydrolysate was then centrifuged at $10,000 \mathrm{~g}$ for $2 \mathrm{~min}$ at $4{ }^{\circ} \mathrm{C}$, and finally, freeze-dried and stored at $-20^{\circ} \mathrm{C}$.

\section{Study of the iron(II)-peptide complex formation}

To work in biologically relevant conditions, iron solutions were prepared as acetate solutions mimicking intracellular labile iron pool in which iron is in a free chelatable and redox-active form $[1,31]$. 
Iron(II) solution was prepared with a 4-fold excess of acetate as iron(II) $(25 \mathrm{mM})$ /acetate $(100 \mathrm{mM})$. Iron(II) chloride $\left(\mathrm{FeCl}_{2}\right)$ was initially dissolved in glacial acetic acid before its dilution in pure water $(\mathrm{pH}=2.7)$. The solution was then filtrated twice. Iron(III) solution was prepared similarly using iron(III) chloride $\left(\mathrm{FeCl}_{3}\right)(\mathrm{pH}=1.9)$. All complexation tests were carried out at room atmosphere.

Two control samples were prepared for each complexation test: the first one in absence of iron and the other one with iron(III), under strictly identical concentration conditions than in the presence of iron(II).

\section{Complexation by pure peptide}

The complexation studies were first carried out for each peptide individually. The stock solution of each peptide $\left(10 \mathrm{~g} \mathrm{~L}^{-1}, 300 \mu \mathrm{L}\right)$ was first diluted with pure water $(100 \mu \mathrm{L})$ to get a peptide solution at $7.5 \mathrm{~g} \mathrm{~L}^{-1}$ $(400 \mu \mathrm{L})$. The $\mathrm{pH}$ was adjusted, if necessary, just below pH 3.0 with $0.1 \mathrm{M}$ $\mathrm{HCl}$, to optimize further solubilization of iron salt. Then, previously prepared solution of iron(II) acetate $(25 \mathrm{mM}, 100 \mu \mathrm{L})$ was added to the former peptide solution $\left(7.5 \mathrm{~g} \mathrm{~L}^{-1}, 400 \mu \mathrm{L}\right)$ to get the final reaction mixture $(500 \mu \mathrm{L})$.

The $\mathrm{pH}$ was finally adjusted around $\mathrm{pH} 3.0$ using aqueous ammonia $(0.25 \%, \mathrm{w} / \mathrm{v})$ as suggested by Silva et al [32]. The peptide to iron concentration ratio comprised between 1 for the longest peptide (LLPHHADADY) and 5.4 for the shortest one ( $\beta A H)$ (ESM Table S2).

\section{Complexation in hydrolysates}

The complexation studies were similarly carried out with either the synthetic or tryptic casein hydrolysates. First, the hydrolysate $(461.5 \mu \mathrm{L})$ and the $\mathrm{GGH}$ peptide solution $\left(\mathrm{C}_{\mathrm{GGH}}, 38.5 \mu \mathrm{L}\right)$ were mixed for $30 \mathrm{~s}$ to get the final peptide solution $(500 \mu \mathrm{L})$. Different concentrations of GGH were used, i.e., $1 \mathrm{~g} \mathrm{~L}^{-1}, 0.1 \mathrm{~g} \mathrm{~L}^{-1}$, and $0.01 \mathrm{~g} \mathrm{~L}^{-1}$. In the GGH-spiked hydrolysates, the $\mathrm{pH}$ values were adjusted below $\mathrm{pH} 3.0$ with $0.1 \mathrm{M} \mathrm{HCl}$. Then, iron(II) acetate solution $(25 \mathrm{mM}, 100 \mu \mathrm{L})$ was added to $400 \mu \mathrm{L}$ of the hydrolysate enriched in GGH to get the final reaction mixture $(500 \mu \mathrm{L})$. The $\mathrm{pH}$ value was finally adjusted around 3.0 with aqueous 
ammonia $(0.25 \%, \mathrm{w} / \mathrm{v})($ ESM Table S3).

\section{Flow injection ESI-HRMS}

ESI-HRMS analyses in flow injection were realized on a UHPLC-MS system (Thermo Fisher Scientific, San Jose, CA, USA) consisting in a quaternary U3000 solvent delivery pump connected to a photodiode array detector (PDA) and a LTQ-Orbitrap ${ }^{\mathrm{TM}}$ hybrid mass spectrometer. The

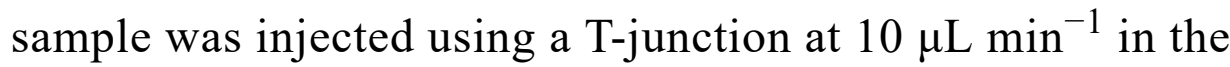
chromatographic mobile phase pumped at $0.2 \mathrm{~mL} \mathrm{~min}^{-1}$. The mobile phase was composed of a 1:1 mixture of (A) aqueous solution of NFPA (5 mM) and (B) methanol. MS analyses were carried out in ESI-positive mode $\left(\mathrm{ESI}^{+}\right)$. The electrospray voltage was $+4.5 \mathrm{kV}$. The capillary temperature was $300^{\circ} \mathrm{C}$. Sheath, auxiliary, and sweep gas flows were set at 40,5 , and 5 (arbitrary units), respectively. Capillary voltage was $46 \mathrm{~V}$. The tube lens, split lens, and front lens voltages were $112 \mathrm{~V},-70 \mathrm{~V}$, and $-6.25 \mathrm{~V}$, respectively. Ion optics parameters used were previously optimized by automatic tuning using highly stable iron(III)-desferrioxamine complex solution at $0.1 \mathrm{~g} \mathrm{~L}^{-1}$ infused in mobile phase (A/B: 50/50) at a flow rate of $5 \mu \mathrm{L} \mathrm{min}{ }^{-1}$. Full scan MS spectra were performed at high resolution $(R=$ 60,000 at $\mathrm{m} / \mathrm{z} 400$ ) on the Orbitrap ${ }^{\mathrm{TM}}$ analyzer from 120 to $2000 \mathrm{~m} / \mathrm{z}$ to obtain the exact masses of the peptides and iron(II)-peptide complexes. Raw data were processed using the XCALIBUR ${ }^{\text {TM }}$ software program (version 2.1, http://www.thermoscientific.com).

\section{IP-RPLC-ESI-HRMS}

Experiments were carried out on the UHPLC-MS system previously described ("Flow injection ESI-HRMS" section) using the same MS parameters. Sixteen microliters of samples was injected onto a $\mathrm{C}_{18}$ Alltima reverse phase column $(150 \times 2.1 \mathrm{~mm}, 5 \mu \mathrm{m}$-Grace/Alltech, Darmstadt, Germany) equipped with a $\mathrm{C}_{18}$ Alltima pre-column $(7.5 \times 2.1 \mathrm{~mm}, 5 \mu \mathrm{m})$ placed in the oven at $25^{\circ} \mathrm{C}$. The flow rate was $0.2 \mathrm{~mL} \mathrm{~min}^{-1}$ and mobile phases consisted in a mixture of (A) aqueous solution of NFPA $(5 \mathrm{mM})$ and $(\mathrm{B})$ methanol in gradient elution mode.

A short separation program was developed simple samples analysis (i.e., study of the complexation of pure peptides) in $21 \mathrm{~min}$. A linear gradient 
was applied from 5 to $98 \%$ of B for $10 \mathrm{~min}$. A longer separation program of $36 \mathrm{~min}$ was performed for the analysis of hydrolysates. In this case, a linear gradient was applied from 5 to $98 \%$ of B for $25 \mathrm{~min}$.

AQ6

\section{Data processing}

The LC-HRMS raw data were pre-processed using the XCMS online platform (https://xcmsonline.scripps.edu). A two-group comparison analysis was performed between samples incubated with iron(II) and their corresponding iron-free control sample [33]. In practice, raw data of triplicates were subjected to the pairwise experiment using the "HPLCOrbitrap II" standard parameter setting method for feature detection, retention time correction, alignment of chromatographic peaks, and statistic treatment. Peak detection was run with CentWave method $(\Delta \mathrm{m} / \mathrm{z}$ $=2.5 \mathrm{ppm}$, peak width $(10-60)$, signal to noise threshold $=10)$. Retention time correction was achieved with the obiwarp method and alignment with the following parameters $(\operatorname{minfrac}=0.5, \mathrm{bw}=5, \mathrm{mzwid}=0.015)$. The Welch's $t$ test (unequal variance) was used as statistical test method ( $p$ value $<0.05)$. The whole data processing is discussed in the "Automated data processing using a metabolomics-like strategy" section.

\section{Results and discussion}

Rapid and direct screening of relevant iron(II)-chelating antioxidant peptides in complex hydrolysates (Fig. 1c) by LC-MS is based on two essential points:

i. The method should discriminate peptides by their iron(II)-chelating ability. The most interesting chelators are supposed to form strong complexes with iron(II) in solution; moreover, the use of ESI-MS has proven its relevance for the observation of stable non-covalent species $[25,34]$.

ii. The method should reveal the better iron(II) chelators even in complex protein hydrolysates. Use of a selective LC method compatible with mass spectrometry makes it possible to distinguish the possible isomers and isobars. Nevertheless, integrity of iron(II)- 
ligand complex must be preserved along the LC separation to achieve its detection by ESI-MS.

Additionally, to allow a rapid screening of chelating peptides in complex mixtures, i.e., protein hydrolysates, the huge amount of data collected during the LC-MS run requires an automated processing.

\section{Detection of the iron(II)-peptide complexes by ESI- HRMS}

The screening of iron-chelating peptides is based on a differential LCHRMS analysis between an iron-free control sample and the same protein hydrolysate incubated with iron(II). Thus, to provide accurate results, iron(II)-peptide complex must not only be detected in ESI-MS but also be preserved during the LC separation. Developed in the early 2000s, ion-pair reversed phase liquid chromatography coupled to mass spectrometry (IPRPLC-MS) using perfluorinated carboxylic acids is effective for the separation of underivatized amino acids $[35,36]$ and small peptides [37] in positive ion mode. A prerequisite was to ensure that iron(II)-peptide complexes are effectively detectable by $\mathrm{ESI}^{+}$-HRMS in such mobile phases. Therefore, the first step was to infuse peptides in LC conditions. Thus, infusion was conducted at $10 \mu \mathrm{L} \mathrm{min}^{-1}$ in the LC flow $\left(0.2 \mathrm{~mL} \cdot \mathrm{min}^{-1}\right)$, with nonafluoropentanoic acid (NFPA) as ion-pairing agent (for the experimental details, see "Flow injection ESI-HRMS" section). All standard peptides were first infused without any exposure to iron(II) and mass spectra were compared with those obtained from the same peptides put into contact with iron(II) as described by Wu et al [21]. The results presented in Fig. 2 for carnosine $(\beta A H)$ and RKR (both described in the literature as $\mathrm{Fe}^{\mathrm{II}}$ chelators $\left.[15,38,39]\right)$, and WWW illustrate the typical behavior of peptides toward iron(II). For the 25 standard peptides evaluated, mass spectra show a set of new mass peaks for samples in contact with $\mathrm{Fe}^{\mathrm{II}}$ (Table 1) attributable to the monocharged ion $\left[(\mathrm{M}-\mathrm{H})+{ }^{56} \mathrm{Fe}^{\mathrm{II}}\right]^{+}$as described by Lagarrigue et al. [40]. In all cases, the main peak is shifted by $+53.919 \mathrm{u}$ with respect to the protonated peptide $[\mathrm{M}+\mathrm{H}]^{+}$(Fig. 2), corresponding to the complexation of ${ }^{56} \mathrm{Fe}(55.935 \mathrm{u})$ by the peptide $(55.935-2 \times 1.008=53.919)$. Evidence of iron complex formation is reinforced by the isotopic pattern which is in good agreement 
with the natural relative abundances of ${ }^{54} \mathrm{Fe}(5.85 \%)$ and ${ }^{56} \mathrm{Fe}(91.75 \%)$. A series of control experiments was carried out with iron(III) to exclude potential oxidation of ferrous ion to ferric ion under $\mathrm{ESI}^{+}$conditions.

Noteworthy, standard peptides incubated with iron(III) show the formation of complex ions $\left[(\mathrm{M}-2 \mathrm{H})+\mathrm{Fe}^{\mathrm{III}}\right]^{+}$which cannot be confused with [(M$\left.\mathrm{H})+\mathrm{Fe}^{\mathrm{II}}\right]^{+}$observed after exposure to iron(II). Whatever the standard peptide incubated with iron(II), formation of complex ion $\left[(\mathrm{M}-2 \mathrm{H})+\mathrm{Fe}^{\mathrm{III}}\right]^{+}$ was never observed meaning that the iron(II) complex is stable enough to prevent its oxidation.

\section{Fig. 2}

ESI-HR mass spectra obtained by flow injection analysis in the presence of iron(II) for a $\beta A H, \mathbf{b}$ RKR, and $\mathbf{c} W W W$. The isotopic pattern of each complex $\left[(\mathrm{M}-\mathrm{H})+\mathrm{Fe}^{\mathrm{II}}\right]^{+}$detailed in the dashed inset showing relative contribution of ${ }^{54} \mathrm{Fe}$ and ${ }^{56} \mathrm{Fe}$

AQ7

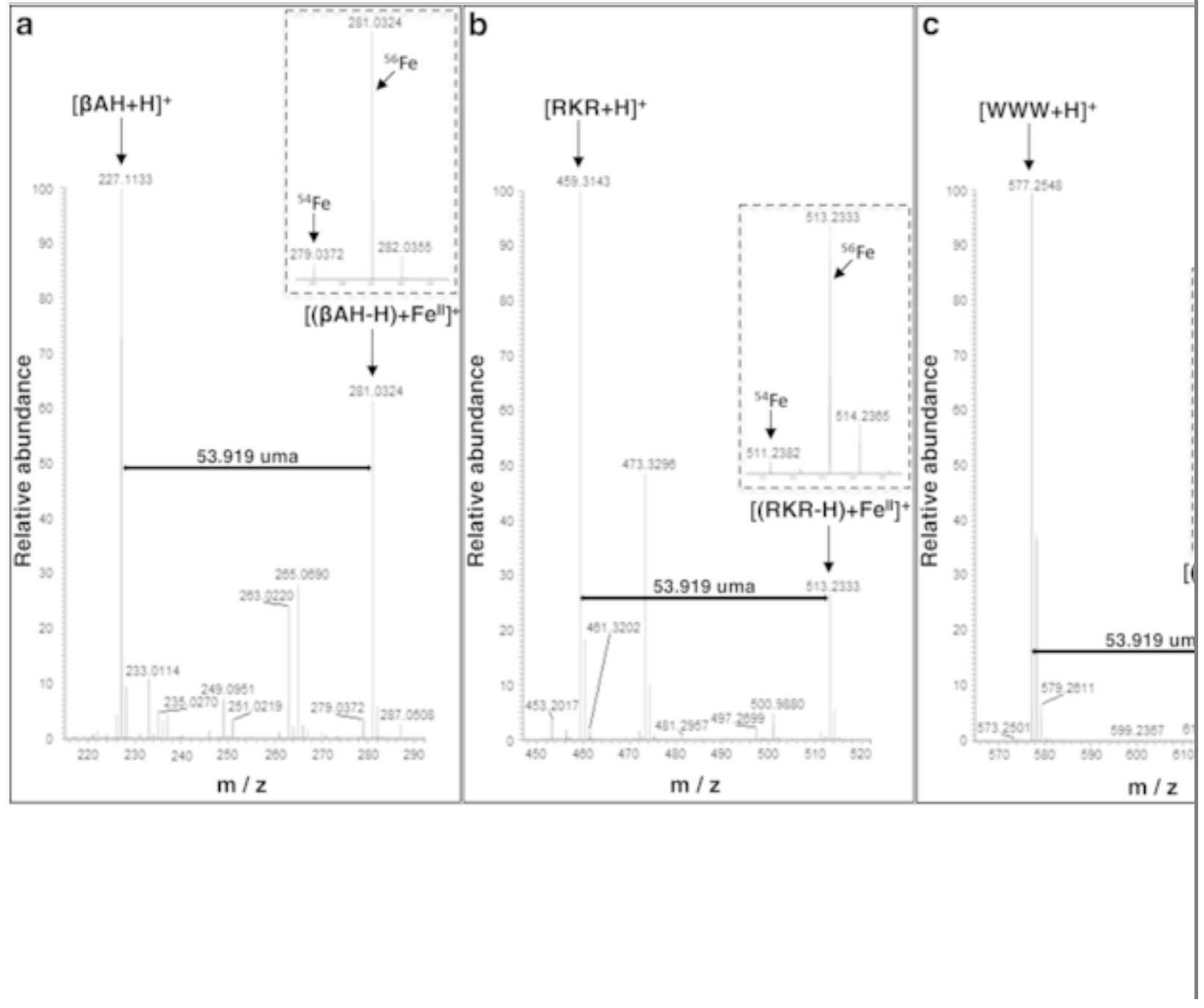




\section{Table 1}

Retention times and observed masses obtained from the IP-RPLC-ESI ${ }^{+}$-HRMS analysis (short time gradient) for the free peptides and their iron(II) complex. RAC values are calculated according to Eq. 1

AQ8

\section{Free peptide}

Peptide

$\mathrm{CAH}$

GGH

EAH

DAH

$\beta A H$

$\mathrm{DMH}$

DTH

DSH

FDDDK

FDDDA

$\mathrm{HGH}$

IKP

LLPHHADADY

RQR

$\mathrm{HHH}$

HHHHHH

RKR

WWW

YPISL

EEE

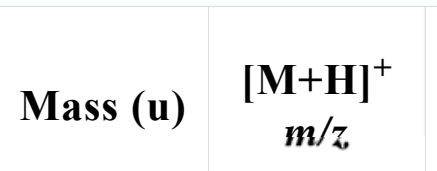

329.113

\begin{tabular}{l|l}
269.111 & 270.119
\end{tabular}

$355.148 \quad 356.156$

$341.132 \quad 342.140$

226.105

227.113

401.135

402.143

371.143

372.151

638.252
639.260

356.241

357.249

458.269

459.277

\begin{tabular}{l|l}
429.186 & 430.194
\end{tabular}

\begin{tabular}{|l|l|}
840.363 & 841.371 \\
\hline
\end{tabular}

\begin{tabular}{l|l|l}
576.247 & 577.255
\end{tabular}

\begin{tabular}{l|l}
591.325 & 592.333
\end{tabular}

\begin{tabular}{l|l}
405.135 & 406.143
\end{tabular}
$357.127 \quad 358.135$

10.0

10.5

\begin{tabular}{l|l|l}
581.195 & 582.203 & 9.9
\end{tabular}

Ret.
time

(min)

H) $\left.+{ }^{56} \mathrm{Fe}\right]^{+}$

$\mathrm{m} / \mathrm{z}$

\begin{tabular}{l|l}
10.4 & 384.040
\end{tabular}

10.1

10.1

324.038

\begin{tabular}{l|l}
10.1 & 396.059
\end{tabular}

10.1

281.032

\begin{tabular}{l|l}
10.5 & 456.063
\end{tabular}

10.1

426.070

412.054

693.179

636.122

10.9

404.074

10.8

11.1

411.168

1205.469

11.0

10.7

0.7

10.8

513.196

484.113

10.9

0.3

11.2

11.4

895.291

11.4

0.3

11.2

513.233

11.0

0.1

11.9

631.174

11.8

0.1

11.3

646.252

11.1

0.1

8.4

460.062

nd

$<0.1$ 
Free peptide

Iron(II) complex

\begin{tabular}{l|l|l|l|l|l|l|}
\multicolumn{1}{|c|}{ Peptide } & Mass (u) & $\begin{array}{c}{[\mathbf{M}+\mathbf{H}]^{+}} \\
\mathbf{m} / \mathbf{z}\end{array}$ & $\begin{array}{c}\text { Ret. } \\
\mathbf{t i m e} \\
\mathbf{( m i n )}\end{array}$ & $\begin{array}{c}\left.[\mathbf{H})^{+56} \mathbf{F e}\right]^{+} \\
\mathbf{m} / \mathbf{z}\end{array}$ & $\begin{array}{c}\text { Ret. } \\
\text { time } \\
\mathbf{( m i n )}\end{array}$ & $\begin{array}{c}\text { RAC } \\
\mathbf{( \% )}\end{array}$ \\
\hline DED & 377.106 & 378.114 & 7.7 & 432.033 & nd & $<0.1$ \\
\hline DDD & 363.090 & 364.098 & 7.3 & 418.017 & nd & $<0.1$ \\
\hline$\gamma E C G$ & 307.082 & 308.090 & 7.3 & 362.009 & nd & $<0.1$ \\
\hline NCS & 322.093 & 323.101 & 8.0 & 377.020 & nd & $<0.1$ \\
\hline IKW & 445.267 & 446.275 & 11.3 & 500.194 & nd & $<0.1$
\end{tabular}

Positive results of this preliminary set of experiments are essential for development of our future LC-MS protocol for the direct screening of relevant iron(II)-chelating antioxidant peptides in complex hydrolysates. Iron complex formation is not only confirmed by detection of monocharged ion $\left[(\mathrm{M}-\mathrm{H})+\mathrm{Fe}^{\mathrm{II}}\right]^{+}$in $\mathrm{ESI}^{+}$-MS but formed complexes are also stable in the LC mobile phase of the chosen chromatographic system (IP-RPLC with NFPA as ion-pairing agent). Interestingly, complexation with a weakly chelating peptide such as WWW [41] under ESI-MS conditions was favorable enough to detect the corresponding iron(II) salt. The discrimination of this kind of peptides will be discuss later.

\section{Evaluation of IP-RPLC for the screening of iron(II)- chelating peptides by ESI-HRMS}

Reversed phase ion-pair liquid chromatography coupled to mass spectrometry (RP-IPLC-MS) using perfluorinated carboxylic acids has been widely used for separation of amino acids and small hydrophilic peptides. Deperson et al. even showed that addition of nonafluoropentanoic acid in mobile phase provides sensitivities of detection comparable to formic or acetic acids commonly used in mass spectrometry [42]. However, the behavior toward retention of metalpeptide complexes needs to be evaluated and compared to the retention of the free peptide in a view of a differential LC screening. Therefore, IPRPLC method was first tested on each solution of individual iron(II)peptide complex before being transposed to hydrolysates. A 21-min short 
program in gradient elution was applied to separate standard peptides (see details in "Complexation by pure peptide" and "IP-RPLC-ESI-HRMS" sections). The results obtained for 25 model peptides are presented in Table 1.

The retention times of the free peptides and their corresponding iron(II) complexes do not differ by more than \pm 0.2 min. Figures $3 \mathrm{a} 1$ and $\mathrm{b} 1$ show that GGH, DAH, and their respective iron(II) complexes are co-eluted meaning also that the $[\mathrm{M}+\mathrm{H}]^{+}$ion of the free peptide and the corresponding $\left[\mathrm{M}-\mathrm{H}+{ }^{56} \mathrm{Fe}^{\mathrm{II}}\right]^{+}$ion of the complex can be observed on the same mass spectrum (Figs. 3a2 and b2). For six peptides (EEE, DED, DDD, $\gamma E C G$, NCS, and IKW), retention time of complexes could not be determined, showing a very poor affinity for iron(II). For the other 21 peptides, the $\left[(\mathrm{M}-\mathrm{H})+{ }^{56} \mathrm{Fe}^{\mathrm{II}}\right]^{+}$, ion was always detected even for weak chelators as already observed with WWW in section "Detection of the iron(II)-peptide complexes by ESI-HRMS." However, the signal of the $\left[(\mathrm{M}-\mathrm{H})+{ }^{56} \mathrm{Fe}^{\mathrm{II}}\right]^{+}$ion is more intense for strong iron(II) chelators.

\section{Fig. 3}

Results of the IP-RPLC-ESI+-HRMS analysis of GGH and DAH. The chromatographic profiles (extracted ion chromatograms of the $[\mathrm{M}+\mathrm{H}]^{+}$and $\left.\left[(\mathrm{M}-\mathrm{H})+\mathrm{Fe}^{\mathrm{II}}\right]^{+}\right)$are shown in $\mathbf{a} 1$ for $\mathrm{GGH}$ and $\mathbf{b 1}$ for $\mathrm{DAH}$, and the corresponding HRMS spectrum in $\mathbf{a 2}$ and $\mathbf{b 2}$ respectively. The relative abundance of complex (RAC) is calculated according Eq. 1 

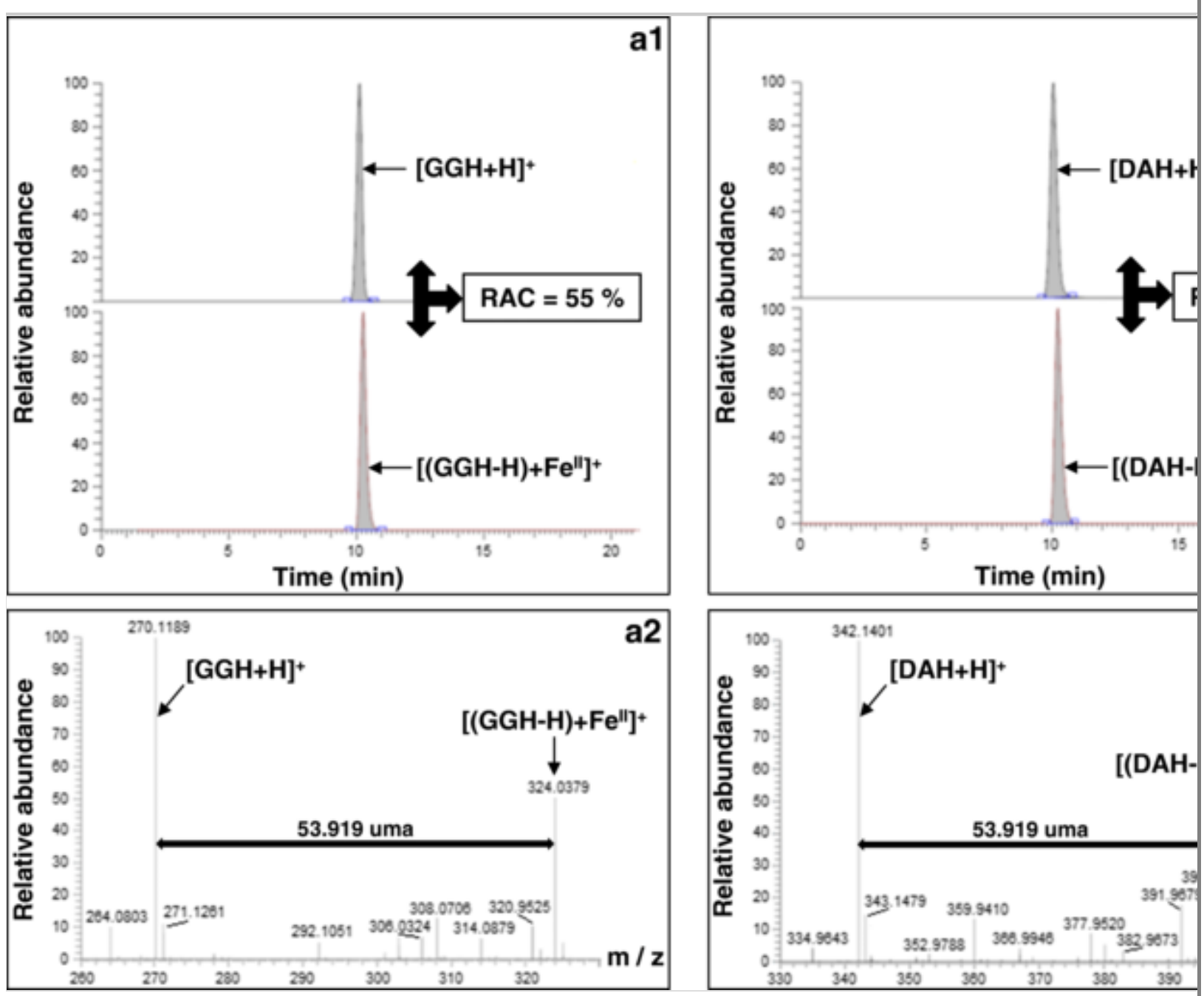

These results demonstrate that IP-RPLC is suitable for a fast LC-ESIHRMS screening method of iron(II)-chelating peptides. Two co-eluted chromatographic peaks separated by $0.2 \mathrm{~min}$ at the most and exhibiting a mass difference of $53.919( \pm 0.001) \mathrm{u}$ between their ion currents might indicate the presence of an iron(II)-chelating peptide. However, their relative intensity needs to be discussed to discriminate peptides of high interest (strong chelators) from the others (weak chelators).

\section{Effect of the iron to peptide ratio on the complex formation}

The relative abundance of the complex

To compare chelating performance of each peptides, their relative abundance of complex (RAC) was defined as the ratio of chromatographic peak area of $\left[(\mathrm{M}-\mathrm{H})+{ }^{56} \mathrm{Fe}^{\mathrm{II}}\right]^{+}$ion $\left(\mathrm{A}_{\text {Complex }}\right)$ to $[\mathrm{M}+\mathrm{H}]^{+}$ion of the free 
peptide $\left(\mathrm{A}_{\text {peptide }}\right)$ expressed as a percentage (Eq. 1).

$$
\mathrm{RAC}=\frac{\mathrm{A}_{\text {Complex }}}{\mathrm{A}_{\text {Peptide }}} \times 100
$$

Thus, the higher the intensity of the $\left[(\mathrm{M}-\mathrm{H})+{ }^{56} \mathrm{Fe}^{\mathrm{II}}\right]^{+}$peak in the mass spectrum, the higher the RAC value. Looking at Table 1, three categories of peptides emerge based on their RAC.

i. A first set of ten peptides emerges with a RAC higher than $10 \%$ (from $11 \%$ for DSH to $82 \%$ for $\mathrm{CAH}$ ) indicating a significant stability of the $\left[\mathrm{M}-\mathrm{H}+{ }^{56} \mathrm{Fe}^{\mathrm{II}}\right]^{+}$complexes during the LC run. Interestingly, all of these tripeptides contain a $\mathrm{C}$-terminal histidine. A tridentate coordination mode involving the terminal $\mathrm{NH}_{2}$, imidazole ring, and terminal $\mathrm{COO}^{-}$ has already been observed with other metals [43] and could explain this high stability of complexes formed between iron(II) and peptide containing histidine in position 3. According to the concept of hard and soft acid base (HSAB) [44], iron(II), as an intermediate Lewis acid, forms more stable coordination complexes with Lewis bases classified as intermediate such as imidazole ring of histidine or terminal $\mathrm{NH}_{2}$. Furthermore, a positive correlation between histidine content and iron-chelating activity has already been observed in purified subfractions of chickpea protein hydrolysates by TorresFuentes et al. in 2012 [19]. It is therefore not surprising that these tripeptides were revealed as the best iron(II) chelators by the proposed method.

ii. At the opposite, because of very weak complex ion signal, RAC value cannot be calculated for the 6 peptides having practically no affinity for iron(II), namely EEE, DED, DDD, $\gamma E C G$, NCS, and IKW. Seven peptides can be added to the list with a RAC value of less than $1 \%$, considered insufficient for an iron(II)-chelating peptide of interest. The tripeptide WWW is in this category with a RAC of $0.1 \%$, whereas intensity of its $\left[\mathrm{M}-\mathrm{H}+{ }^{56} \mathrm{Fe}^{\mathrm{II}}\right]^{+}$ion in infusion was higher with a RAC value of $8 \%$ (based on the mass spectrum in Fig. 2c). This result is in agreement with the fact that only strong coordination complexes can be easily detected after the LC process contrary to 
weak ones [25].

iii. The last group, presenting an intermediate behavior, is composed of four peptides having their RAC values between 1 and 10\%, namely FDDDK, FDDDA, HGH, and IKP. Interestingly, the tripeptide DDD did not complex iron(II), while the pentapeptides FDDDK and FDDDA gave a moderately stable complex with RACs of $7 \%$ and $3.5 \%$, respectively. It seems that additional Phe at the $\mathrm{N}$-terminal of the triacidic backbone may give rise to weak interactions with iron(II) (d- $\pi$ interaction [45]).

These results show that iron(II)-chelating ability may be evaluated from relative abundance of complex (RAC). However, it is worth examining more deeply this factor to use it as a discriminating parameter. This includes definition of relevant threshold value. Indeed, the crucial question is the possible dependence of the RAC values on the starting conditions of the chelate formation, precisely on the iron(II) to peptide concentration ratio.

\section{Effect of [iron]/[peptide] ratio on the RAC}

We studied influence of initial iron(II) to peptide concentration ratio on final RAC value. Due to its high RAC value, the tripeptide GGH was selected to carry out this study rather than carnosine (CAH has been left aside due to its possible dimerization via oxidation of cysteine residue).

The first set of experiment was conducted using a fixed $1 \mathrm{mM}$ concentration of iron(II). The concentration ratio varied from a 10 -fold excess in peptide to a 10 -fold excess of iron. The results on the RAC of GGH are presented in Fig. 4. Curve shows two trends: first, with an iron(II) deficiency (excess of peptide), the RAC value increases rapidly until the ratio $\left[\mathrm{Fe}^{\mathrm{II}}\right] /[$ peptide] reaches 1 . In this area, iron(II) is quickly sequestered to form the chelate. Secondly, in excess of iron(II), the curve increases slowly because complexation reaction is almost complete. The primary conclusion to be drawn from this curve is that the RAC value fluctuates less in excess than in iron deficiency, even if its value depends on $\left[\mathrm{Fe}^{\mathrm{II}}\right] /[$ peptide] ratio. Thus, it would be much better to form chelates in 
excess of iron(II) during sample preparation.

\section{Fig. 4}

Evolution of the relative abundance of complex (RAC) for GGH as a function of the iron(II) to peptide ratio

AQ9

AQ10

\section{RAC (\%)}

\section{[iron(II)]/[GGH]}

To assess a potential matrix effect, a second set of experiments was performed with GGH added to mixtures of increased complexity, respectively, a synthetic hydrolysate composed of non-chelating peptides and a tryptic casein hydrolysate (Table 2). For hydrolysates, an IP-RPLC method of 36 min was applied to improve small peptide separation in complex mixtures (see details in "IP-RPLC-ESI-HRMS" section) especially GGH, which does not co-elute with any other peptide in the synthetic hydrolysate (Fig. 5a). In these new chromatographic conditions, 
the differences of retention time for the complex compared to the free peptide are still below $0.2 \mathrm{~min}$.

\section{Table 2}

Values of the parameters used for the screening of peptides in protein hydrolysates not determined (below the limit of detection or no signal for $\left[(\mathrm{M}-\mathrm{H})+{ }^{56} \mathrm{Fe}^{\mathrm{II}}\right]^{+}$)

\begin{tabular}{|c|c|c|c|c|c|}
\hline Peptide & Matrix & $\begin{array}{c}\text { [peptide] } \\
(\mu \mathrm{M})\end{array}$ & {$\left[\mathrm{Fe}^{\mathrm{II}}\right] /[$ peptide] } & $\begin{array}{c}\text { Retention } \\
\text { times } \\
\text { (min) } \\
\text { peptide } \\
\text { /iron(II) } \\
\text { complex }\end{array}$ & $\begin{array}{c}\text { RAC } \\
(\%)\end{array}$ \\
\hline$\gamma \mathrm{ECG}$ & \multirow{14}{*}{$\begin{array}{l}\text { Synthetic } \\
\text { hydrolysate }\end{array}$} & 190 & 26 & $10.5 / 10.5$ & $<0.5$ \\
\hline NCS & & 180 & 28 & $11.2 / \mathrm{Nd}$ & $\mathrm{Nd}$ \\
\hline IKP & & 160 & 31 & 19.0/19.0 & $\begin{array}{l}1.4 \\
\pm 0.3\end{array}$ \\
\hline DDD & & 160 & 31 & $10.2 / \mathrm{Nd}$ & $\mathrm{Nd}$ \\
\hline DED & & 150 & 33 & $10.8 / \mathrm{Nd}$ & $\mathrm{Nd}$ \\
\hline EEE & & 140 & 36 & $12.4 / \mathrm{Nd}$ & $\mathrm{Nd}$ \\
\hline $\mathrm{HHH}$ & & 130 & 38 & $19.8 / 19.8$ & $\begin{array}{l}1.21 \\
\pm \\
0.03\end{array}$ \\
\hline IKW & & 130 & 38 & $20.6 / 20.6$ & $<0.5$ \\
\hline RKR & & 120 & 42 & $20.0 / 20.0$ & $<0.5$ \\
\hline RQR & & 120 & 42 & $19.3 / 19.3$ & $<0.5$ \\
\hline YPISL & & 100 & 50 & $20.6 / 20.6$ & $<0.5$ \\
\hline ННННН & & 70 & 71 & $21.1 / 21.1$ & $<0.5$ \\
\hline LLPHHADADY & & 50 & 100 & $20.2 / 20.2$ & $<0.5$ \\
\hline GGH & & 231 & 22 & $17.2 / 17.4$ & $\begin{array}{l}115 \\
\pm 1\end{array}$ \\
\hline
\end{tabular}




\begin{tabular}{|c|c|c|c|c|c|}
\hline \multirow[t]{6}{*}{ Peptide } & \multirow[t]{3}{*}{ Matrix } & $\begin{array}{c}\text { [peptide] } \\
(\mu \mathrm{M})\end{array}$ & {$\left[\mathrm{Fe}^{\mathrm{II}}\right] /[$ peptide] } & \multirow[t]{3}{*}{$\begin{array}{c}\text { Retention } \\
\text { times } \\
\text { (min) } \\
\text { peptide } \\
\text { /iron(II) } \\
\text { complex }\end{array}$} & $\begin{array}{c}\text { RAC } \\
(\%)\end{array}$ \\
\hline & & 23.1 & 220 & & $\begin{array}{l}159 \\
\pm 8\end{array}$ \\
\hline & & 2.31 & 2200 & & $\begin{array}{l}125 \\
\pm 14\end{array}$ \\
\hline & \multirow{3}{*}{$\begin{array}{l}\text { Casein } \\
\text { hydrolysate }\end{array}$} & 231 & 22 & \multirow{3}{*}{$17.2 / 17.4$} & $\begin{array}{l}126 \\
\pm 3\end{array}$ \\
\hline & & 23.1 & 220 & & $\begin{array}{l}279 \\
\pm 3\end{array}$ \\
\hline & & 2.31 & 2200 & & $\begin{array}{l}281 \\
\pm 10\end{array}$ \\
\hline
\end{tabular}

Fig. 5

IP-RPLC-ESI-HRMS (long time gradient) total ion current chromatogram of the hydrolysates spiked with GGH at $77 \mathrm{mg} \mathrm{L}^{-1}$. a Synthetic hydrolysate and b Casein tryptic hydrolysate
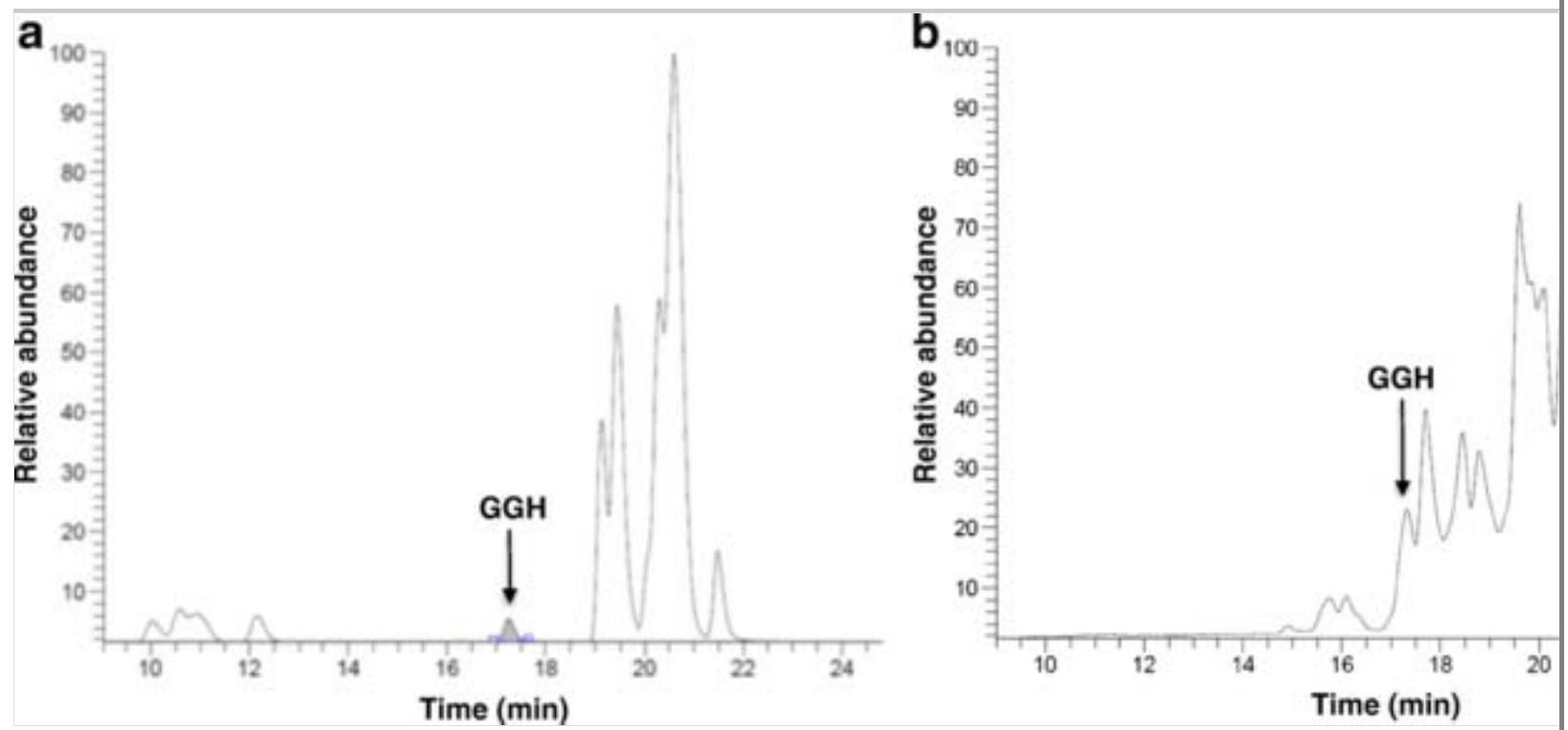

Each hydrolysate was injected without incubation with iron(II) (control sample) and after incubation with iron(II) in excess. In the case of the 
synthetic hydrolysate, the RAC are less than $0.8 \%$ in the control sample for all the peptides, including GGH. After contact with iron(II), GGH is the only peptide with a significant increasing value of its RAC, outreaching $100 \%$ whatever the $[\mathrm{FeII}] /[\mathrm{GGH}]$ ratio tested. The same tendencies are observed for the casein tryptic hydrolysate (Fig. 5b and Table 2).

\section{Combination of up and downregulation factors}

As previously seen, determination of RAC does not require exploring the results of a control sample obtained without $\mathrm{Fe}^{\mathrm{II}}$ contact. Nevertheless, another interesting approach to screen metal ion chelators is precisely to compare the same sample incubated, or not, with iron(II). A potential candidate to iron chelation must necessarily provide an increase of the $\left[(\mathrm{M}-\mathrm{H})+{ }^{56} \mathrm{Fe}^{\mathrm{II}}\right]^{+}$peak, while, in the same time, the $[\mathrm{M}+\mathrm{H}]^{+}$peak must conversely decrease. Two parameters can be calculated to express these concomitant events. The upregulation factor of the complex is expressed as the ratio of chromatographic peak area of $\left[(\mathrm{M}-\mathrm{H})+{ }^{56} \mathrm{Fe}^{\mathrm{II}}\right]^{+}$in incubation reported to control sample (Eq. 2):

$$
\mathrm{Up} \text { factor }=\frac{\mathrm{A}_{\text {Complex (incubation) }}}{\mathrm{A}_{\text {Complex (control) }}}
$$

In control samples, no complex should be detected and corresponding peak area $\left(\mathrm{A}_{\text {Complex (control) }}\right)$ is expected equal to zero. As a result, $\mathrm{RAC}$ and up factor cannot be determined. However, in control samples, a weak residual signal is often detected (and automatically integrated by the MS software) for the complex ion at the retention time of the corresponding free peptide $\pm 0.2 \mathrm{~min}$. A probable assumption is that iron(II) is released by weak chelator peptides, samples after samples, maintaining a trace level of metal ion in the LC-MS system. Nevertheless, calculation of up factor is then possible and its value must be compared to corresponding down factor.

The down factor is expressed as the ratio of the chromatographic peak area of the $[\mathrm{M}+\mathrm{H}]^{+}$ion in the control reported to incubated sample (Eq. 3): 
Down factor $=\frac{A_{\text {Peptide (control) }}}{A_{\text {peptide (incubation) }}}$

In this approach, both factors increase together in the presence of iron(II)chelating peptides. Indeed, for a chelating species, the appearance of the $\left[(\mathrm{M}-\mathrm{H})+{ }^{56} \mathrm{Fe}^{\mathrm{II}}\right]^{+}$is correlated to concomitant disappearance of $[\mathrm{M}+\mathrm{H}]^{+}$. This is precisely what was observed in Table 2 for synthetic hydrolysate. Even if some peptides display a slight increase in their up factor, their down factor shows no significant change in the chromatographic peak area of the $[\mathrm{M}+\mathrm{H}]^{+}$ion (down factor $=1$ ). GGH is the only one showing the right tendencies with an increasing value of both factors. Thus, even if up and down factors measure different ionic species with most likely unequal sensitivity, the upregulation of the $\left[\mathrm{M}-\mathrm{H}+{ }^{56} \mathrm{Fe}^{\mathrm{II}}\right]^{+}$peak together with the downregulation of the $[\mathrm{M}+\mathrm{H}]^{+}$peak can be associated to the RAC as filters for the future screening of iron(II)-chelating peptides by LC-ESI-HRMS.

\section{Automated data processing using a metabolomics-like strategy}

The first part of the work has shown the technical feasibility of a screening test for highlighting iron(II)-chelating peptides by IP-RPLC-ESI-HRMS in hydrolysates. First, it was possible to detect by MS the iron(II)-peptide complex with a systematic offset by $+53.919 \mathrm{u}$ with respect to free peptide ion. Second, it was observed that a given peptide and its associated iron(II)-complex have retention times in IP-RPLC whose difference does not exceed $0.2 \mathrm{~min}$. Together, both parameters evidence the formation of an iron(II) complex without providing any information about the complexation efficiency. This can be achieved through correlation between both up and down factors, and the RAC after the comparison of samples put into contact or not with iron(II). Nevertheless, in a protein hydrolysate, the large amount of collected data readily put a brake to manual processing. Consequently, a metabolomics-like approach has been evaluated for an automated processing of the IP-RPLC-ESI-HRMS data. Figure 6 provides an overview of final screening process and automated data processing.

Fig. 6 
Detailed overview of the non-targeted protocol combining a differential IPRPLC-ESI-HRMS analysis and a metabolomics-like data processing for the screening of peptides with high iron(II)-chelating abilities. Peptide code: peptides $\mathrm{B}, \mathrm{C}$, and $\mathrm{D}$ do not have any chelating property, $\mathrm{E}$ and $\mathrm{J}$ are weak chelators, $\mathrm{A}$ is of average strength, and $\mathrm{F}$ is strong. Compounds $\mathrm{s}$ to $\mathrm{z}$ are potential impurities

\section{I] Sample preparation}

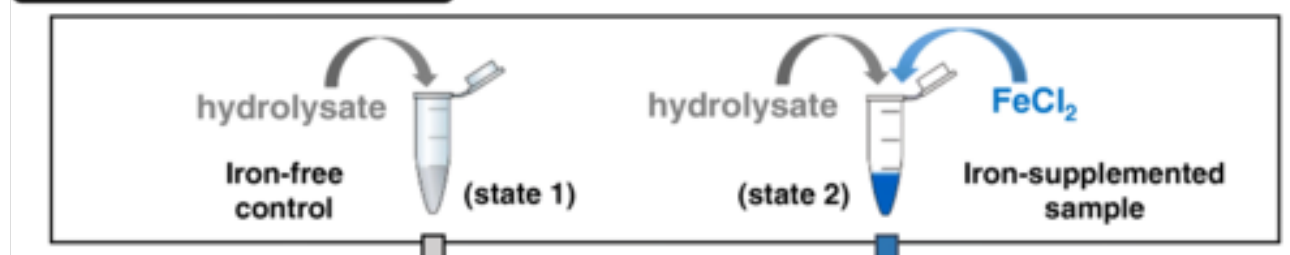

\section{II] Data acquisition}

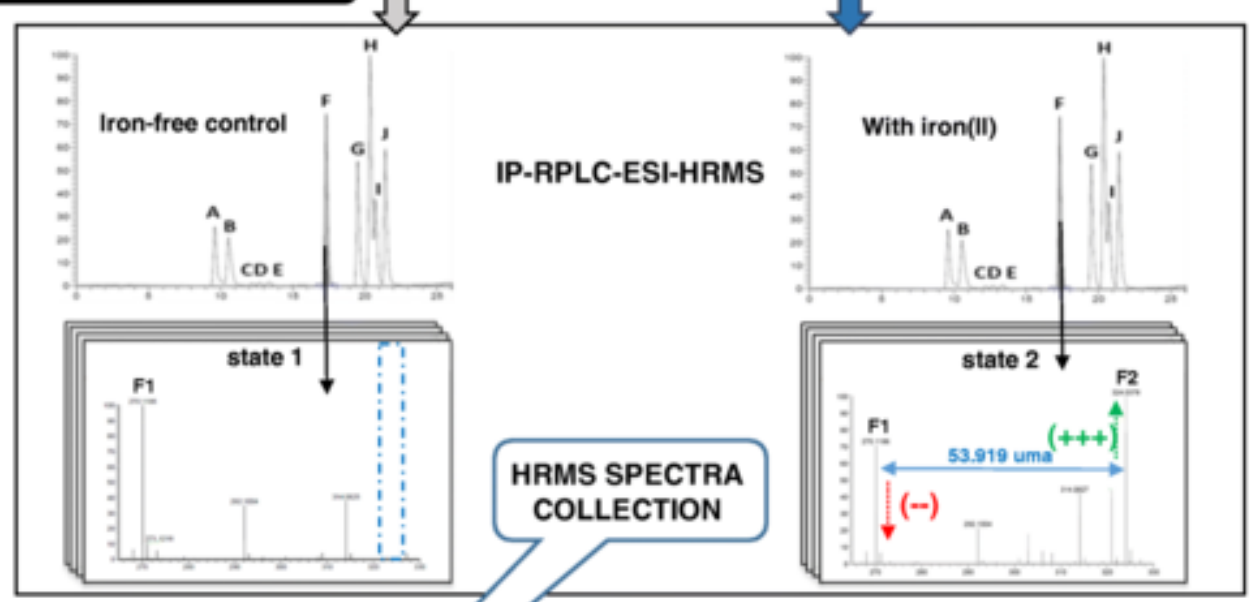

\section{III] Data processing}

\begin{tabular}{|c|c|c|c|}
\hline $\begin{array}{l}\text { PAIRWISE } \\
\text { ANALYSIS }\end{array}$ & & $\begin{array}{l}\Delta M=53,919 \pm 0,001 u \\
\left(\text { screening filter } n^{\circ} 1\right)\end{array}$ & $\begin{array}{c}\text { A1 (-)/ A2 }(+) \\
\text { F1 (-) / F2 (+++) } \\
\mathbf{y}(-) / \mathbf{z}(+)\end{array}$ \\
\hline $\begin{array}{l}\text { A1 (-) } \\
\mathbf{~ s ~ ( - ) ~} \\
\text { A2 }(+) \\
\text { t }(+)\end{array}$ & \multirow{3}{*}{ 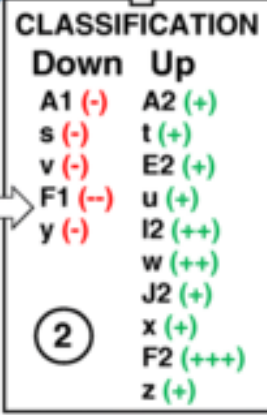 } & $\begin{array}{l}\Delta \text { Ret. time } \leq 0.2 \mathrm{~min} \\
\left(\mathrm{screening} \text { filter } \mathrm{n}^{\circ} 2\right)\end{array}$ & $\begin{array}{c}\text { A1 (-)/A2 }(+) \\
\text { F1 (-)/F2 }(+++) \\
\text { y }(-) / \mathbf{z}(+)\end{array}$ \\
\hline $\begin{array}{l}\text { E2 }(+) \\
\mathbf{u}(+) \\
\mathbf{I} 2(++) \\
\mathbf{V}(-) \\
\mathbf{W}(++) \\
\text { F1 }(-)\end{array}$ & & $\begin{array}{l}\text { Up factor }>10 \\
\quad+ \\
\text { Down factor }>1.33 \\
\text { (screening filter } n^{\circ} 3 \text { and }\end{array}$ & $\begin{array}{l}\mathrm{F1}(--) / \mathrm{F} 2(+++) \\
4)\end{array}$ \\
\hline $\begin{array}{l}\mathbf{J} 2(+) \\
\mathbf{X}(+) \\
\mathbf{F} 2(+++)\end{array}$ & & $\begin{array}{c}\text { RAC > } 50 \% \\
\text { (screening filter } n^{\circ} 5 \text { ) }\end{array}$ & F1 (-)/F2 (+++) \\
\hline $\begin{array}{l}\mathbf{y}(-) \\
\mathbf{z}(+)\end{array}$ & & $\begin{array}{l}\text { F retained as peptid } \\
\text { iron(II)-chelating }\end{array}$ & $\begin{array}{l}\text { e with high } \\
\text { abilities }\end{array}$ \\
\hline
\end{tabular}

The first step (step I) of screening is sample generation. The hydrolysate is 
put into contact with iron(II) (state 2) for later comparison with the same hydrolysate without any contact with iron (control sample - state 1). Both samples are injected into the LC-ESI-HRMS system (step II). Two independent data sets of high-resolution mass spectra are collected and submitted to the automated data process (step III). Step III comprises several levels. Thanks to metabolomics XCMS software, based on the variation of chromatographic areas, a list of up- and downregulated MS signals is extracted (step III-(1)). Up- and downregulated signals are separated to constitute two different lists thanks to MATLAB (step III-(2)). Obviously, the $\left[(\mathrm{M}-\mathrm{H})+{ }^{56} \mathrm{Fe}^{\mathrm{II}}\right]^{+}$are expected in the list of the upregulated signals (marked with + in Fig. 6), whereas the corresponding free peptides $[\mathrm{M}+\mathrm{H}]^{+}$are expected in the downregulated list (marked with -). An optional step could be performed by eliminating downregulated features (potential peptides) whose area does not meet minimum area criterion set for state 1 (control).

Then, some filters can be applied to highlight peptides of interest. The two first filters are qualitative applying expected accurate shift of 53.919 \pm $0.001 \mathrm{u}$ (step III-3) and a maximum difference less than $0.2 \mathrm{~min}$ for retention time between the free peptide and its corresponding iron(II) complex (step III-44).

Table 3 summarizes the results obtained on the synthetic and the casein hydrolysates spiked with GGH at $28.6 \mu \mathrm{M}$ or $2.86 \mu \mathrm{M}$ following the pairwise analysis step. The number of down- and upregulated signals looks impressive (step III-(1)) even for simple synthetic hydrolysate, but applying the two first qualitative filters (step III-(3) and (4)), this number drops significantly. Starting from a little bit less than two thousand, only 22 signals remain after applying the mass and the retention time filters. The same goes for the casein hydrolysate with only slightly more than 40 signals remaining. As expected, signals corresponding to GGH and its iron(II) complex belong to the list.

\section{Table 3}

Results of the step-by-step data processing presented in Fig. 6 for the hydrolysates spiked with GGH at $7.7 \mathrm{mg} \mathrm{L}^{-1}(28.6 \mu \mathrm{M})$, and at $0.77 \mathrm{mg} \mathrm{L}^{-1}(2.86 \mu \mathrm{M})$

\section{\begin{tabular}{c|c|c|c} 
Hydrolysate & $\mathrm{C}_{\mathrm{GGH}}$ & Number of & Number of remaining candidate ion
\end{tabular}}


significant

features

pairs

$\left(m g L^{-1}\right)$

\begin{tabular}{|c|c|c|c|}
\hline $\begin{array}{c}\text { Pairwise } \\
\text { analysis (1) }\end{array}$ & $\begin{array}{l}\text { Mass } \\
\text { offset } \\
\text { (2) }\end{array}$ & $\begin{array}{l}\text { Retention } \\
\text { time } \\
\text { offset (3) }\end{array}$ & $\begin{array}{c}\text { Up + } \\
\text { down } \\
\text { factors }\end{array}$ \\
\hline
\end{tabular}

Synthetic

7.7

$1662(354$

$d^{\mathrm{a}}+1308$

36

$\mathrm{u}^{\mathrm{b}}$ )

(1)*

22

7

2

\begin{tabular}{l|l}
7.7 & $1885(1071$ \\
& $d+814 u)$
\end{tabular}

67

$(23)^{*}$

43

36

9

Casein

\begin{tabular}{l|l|l}
0.77 & $1330(578$ & 47 \\
$\mathrm{~d}+752 \mathrm{u})$ & $(43)$
\end{tabular}

47
$(43) *$

42

33

6

${ }^{a} d$ : feature significantly downregulated between the control (without iron) and the test with iron(II)

${ }^{b} \mathrm{u}$ : feature significantly upregulated between the control (without iron) and the test with iron(II)

*Rank of GGH and its complex (270.1189-324.0379) according to the $p$ value (Welch's $t$ test)

Quantitative filters are then applied to discriminate relevant chelating peptides through the correlation between up and down factors (step III-(5)), and the RAC (step III-(6). In our example, we applied a fold up superior to 10 and a fold down of 1.3 followed by a filtration with a RAC value higher than $50 \%$ (the chromatographic area of the $\left[(\mathrm{M}-\mathrm{H})+{ }^{56} \mathrm{Fe}^{\mathrm{II}}\right]^{+}$ion representing in this case at least one-half of the area measured for the $[\mathrm{M}+\mathrm{H}]^{+}$ion). However, each experimenter can move the cursor of each quantitative parameter depending on its own interest (to obtain weaker or stronger chelators). After the last step, only two signals remain in the synthetic hydrolysate, and after a careful examination, both signals are belonging to $\mathrm{GGH}$. The first one is the monoisotopic $[\mathrm{GGH}+\mathrm{H}]^{+}$at $\mathrm{m} / \mathrm{z}$ 270.119 and the second one is the second isotopic peak of $[\mathrm{GGH}+\mathrm{H}]^{+}$at $\mathrm{m} / \mathrm{z} 271.122$ due to the natural abundance of ${ }^{13} \mathrm{C}$. The same tendencies were observed for casein hydrolysate spiked with GGH (Table 3). GGH also appeared as lead peptide on RAC criterion even at very low concentration $(2.86 \mu \mathrm{M})$. Casein hydrolysate presents a few additional signals after the last filter was applied, compared to synthetic hydrolysate. 
Those signals are certainly due to unknown iron(II)-chelating casein peptides whose structure will be determined in the future.

Lastly, all filtering procedures are detailed gradually in Table 3 to figure out progression in data processing. The whole process could of course be achieved in one step involving a pivot table.

\section{Conclusion}

The main goal of this work was to set up an innovative integrated protocol for direct and sensitive screening of peptides with high iron(II)-chelating abilities in complex mixtures. A methodology based on IP-RPLC-ESIHRMS using NFPA as ion paring reagent was developed for highlighting these stable complexes. A simple pairwise analysis between control samples and samples put in contact with $\mathrm{Fe}^{\mathrm{II}}$ followed by an adequate data filtering made possible the detection of effective iron(II) chelators in more or less complex mixtures such as casein tryptic hydrolysate, even at very low concentration (few $\mu \mathrm{M}$ ). This new analytical approach represents a significant progress over conventional techniques (empirical protocol and protocol based on IMAC) for detection of iron(II)-chelating peptides. This method is simple (easy sample preparation followed by a single analytical step) and rapid (the entire protocol takes only few hours to highlight candidates compared to few months for empirical approach). It is also highly sensitive and directly provides structural information thanks to online MS detection. Finally, once peptides of interest have been identified in some hydrolysates, it is much easier to focus on their purification. The perspective of this work is its extension to new applications for highlighting new peptide candidates - and thus new drug and nutraceutical candidates - in complex mixtures such as other protein hydrolysates. In addition to their potential benefit against oxidative stress, iron(II)chelating peptides can also be used for iron fortification. Indeed, iron chelates are considered an excellent alternative to poor bioavailable ferrous salts [21, 46]. This approach could be obviously extended to other metal chelation and completed by tandem mass spectrometry experiments for structural elucidation as suggested by the first experiments carried out on GGH used as model in this work (ESM Fig. S1). 
Springer Nature remains neutral with regard to jurisdictional claims in published maps and institutional affiliations.

\section{Acknowledgments}

The authors acknowledge support of the "Laboratory of engineering of Biomolecules" and of the "Laboratory Reactions and Chemical Engineering" by the "Impact Biomolecules" project of the "Lorraine Université d'Excellence" (Investissements d'avenir - ANR-15-IDEX-04LUE).

\section{Authors' contributions}

CP performed and designed the different experiments. CP and PC wrote the manuscript. KS provided scientific support on the complexation part and thoroughly corrected the manuscript. BE performed calculations on MATLAB software. LS and GC synthetized two standard peptides. CCK provided the casein tryptic hydrolysate. SD, LCR, PC, and KS supervised the global research. All authors critically reviewed the manuscript.

Data availability

The datasets generated during and/or analyzed during the current study are not publicly available (currently in progress in our establishment) but are available from the corresponding author on reasonable request.

Compliance with ethical standards

Conflict of interest The authors declare that they have no competing interest.

\section{Supplementary information}

\section{ESM 1}

(PDF $203 \mathrm{~kb})$

\section{References}

1. Kakhlon O, Cabantchik ZI. The labile iron pool. Free Radic Biol 
Med. 2002;33(8):1037-46.

2. Patel M, Ramavataram DVSS. Non transferrin bound iron: nature, manifestations and analytical approaches for estimation. Indian J Clin Biochem. 2012;27(4):322-32.

3. Liu R, Xing L, Fu Q, Zhou G, Zhang W. A review of antioxidant peptides derived from meat muscle and by-products. Antioxidants. 2016;5(3):32.

4. Walters M, Esfandi R, Tsopmo A. Potential of food hydrolyzed proteins and peptides to chelate iron or calcium and enhance their absorption. Foods. 2018;7(10):172.

5. Hepel M, Andreescu S. Oxidative stress and human health. In: Hepel $\mathrm{M}$, Andreescu S, editors. Oxidative stress: diagnostics, prevention, and therapy Volume 2. ACS Symposium Series 1200; 2015. p. 1-33.

6. Sánchez A, Vázquez A. Bioactive peptides: a review. Food Qual Saf. 2017;1(1):29-46.

7. Chakrabarti S, Guha S, Majumder K. Food-derived bioactive peptides in human health: challenges and opportunities. Nutrients. 2018;10(11):1738.

8. Li-Chan EC. Bioactive peptides and protein hydrolysates: research trends and challenges for application as nutraceuticals and functional food ingredients. Curr Opin Food Sci. 2015;1:28-37.

9. Ding X-P, Wang X-T, Chen L-L, Guo Q, Wang H, Qi J, et al. On-line high-performance liquid chromatography-diode array detectionelectrospray ionization-mass spectrometry-chemiluminescence assay of radical scavengers in Epimedium. J Chromatogr A. 2011;1218(9):1227-35.

10. Raudonis R, Bumblauskiene L, Jakstas V, Pukalskas A, Janulis V. Optimization and validation of post-column assay for screening of 
radical scavengers in herbal raw materials and herbal preparations. J Chromatogr A. 2010;1217(49):7690-8.

11. Koleva II, Niederländer HAG, van Beek TA. An on-line HPLC method for detection of radical scavenging compounds in complex mixtures. Anal Chem. 2000;72(10):2323-8.

12. Kim SH, Lee JY, Balolong MP, Kim J-E, Paik H-D, Kang D-K. Identification and characterization of a novel antioxidant peptide from bovine skim milk fermented by Lactococcus lactis SL6. Food Sci Anim Resour. 2017;37(3):402-9.

13. Porath J. High-performance immobilized-metal-ion affinity chromatography of peptides and proteins. J Chromatogr A. 1988;443:3-11.

14. Lv Y, Wei K, Meng X, Huang Y, Zhang T, Li Z. Separation and identification of iron-chelating peptides from defatted walnut flake by nanoLC-ESI-MS/MS and de novo sequencing. Process Biochem. 2017;59:223-8.

15. Wang C, Li B, Ao J. Separation and identification of zinc-chelating peptides from sesame protein hydrolysate using IMAC-Zn2+ and LCMS/MS. Food Chem. 2012;134(2):1231-8.

16. Lv Y, Bao X, Liu H, Ren J, Guo S. Purification and characterization of calcium-binding soybean protein hydrolysates by $\mathrm{Ca} 2+/ \mathrm{Fe} 3+$ immobilized metal affinity chromatography (IMAC). Food Chem. 2013;141(3):1645-50.

17. Caetano-Silva ME, Alves RC, Lucena GN, Frem RCG, BertoldoPacheco MT, Lima-Pallone JA, et al. Synthesis of whey peptide-iron complexes: influence of using different iron precursor compounds. Food Res Int. 2017;101:73-81.

18. Megías C, Pedroche J, Yust MM, Girón-Calle J, Alaiz M, Millán F, et al. Affinity purification of copper-chelating peptides from sunflower 
protein hydrolysates. J Agric Food Chem. 2007;55(16):6509-14.

19. Torres-Fuentes C, Alaiz M, Vioque J. Iron-chelating activity of chickpea protein hydrolysate peptides. Food Chem. 2012;134(3):1585-8.

20. Torres-Fuentes C, Alaiz M, Vioque J. Affinity purification and characterisation of chelating peptides from chickpea protein hydrolysates. Food Chem. 2011;129(2):485-90.

21. Wu W, Li B, Hou H, Zhang H, Zhao X. Identification of ironchelating peptides from Pacific cod skin gelatin and the possible binding mode. J Funct Foods. 2017;35:418-27.

22. Guo L, Hou H, Li B, Zhang Z, Wang S, Zhao X. Preparation, isolation and identification of iron-chelating peptides derived from Alaska pollock skin. Process Biochem. 2013;48(5-6):988-93.

23. Gutiérrez R, Martín del Valle EM, Galán MA. Immobilized metalion affinity chromatography: status and trends. Sep Purif Rev. 2007;36(1):71-111.

24. Marco VBD, Bombi GG. Electrospray mass spectrometry (ESIMS) in the study of metal-ligand solution equilibria. Mass Spectrom Rev. 2006;25(3):347-79.

25. Keith-Roach MJ. A review of recent trends in electrospray ionisation-mass spectrometry for the analysis of metal-organic ligand complexes. Anal Chim Acta. 2010;678(2):140-8.

26. Gizzi P, Henry B, Rubini P, Giroux S, Wenger E. A multi-approach study of the interaction of the $\mathrm{Cu}(\mathrm{II})$ and $\mathrm{Ni}(\mathrm{II})$ ions with alanylglycylhistamine, a mimicking pseudopeptide of the serum albumine N-terminal residue. J Inorg Biochem. 2005;99(5):1182-92.

27. Jancsó A, Selmeczi K, Gizzi P, Nagy NV, Gajda T, Henry B. The role of terminal amino group and histidine at the fourth position in the 
metal ion binding of oligopeptides revisited: copper(II) and nickel(II) complexes of glycyl-glycyl-glycyl-histamine and its N-Boc protected derivative. J Inorg Biochem. 2011;105(1):92-101.

28. Selmeczi K, Gizzi P, Champmartin D, Rubini P, Aubert E, Dahaoui $\mathrm{S}$, et al. Nickel(II)-dipeptidoamine-based tetrameric complex: structural study in solution and in solid state. Inorg Chem. 2010;49(18):8222-9.

29. Grimble GK. The significance of peptides in clinical nutrition. Annu Rev Nutr. 1994;14(1):419-47.

30. Csire G, Canabady-Rochelle L, Averlant-Petit M-C, Selmeczi K, Stefan L. Both metal-chelating and free radical-scavenging synthetic pentapeptides as efficient inhibitors of reactive oxygen species generation. Metallomics. 2020. https://doi.org/10.1039/D0MT00103A.

31. Halliwell B. Protection against tissue damage in vivo by desferrioxamine: what is its mechanism of action? Free Radic Biol Med. 1989;7(6):645-51.

32. Silva AMN, Kong X, Parkin MC, Cammack R, Hider RC. Iron(iii) citrate speciation in aqueous solution. Dalton Trans. 2009;40:8616.

33. Gowda H, Ivanisevic J, Johnson CH, Kurczy ME, Benton HP, Rinehart D, et al. Interactive XCMS online: simplifying advanced metabolomic data processing and subsequent statistical analyses. Anal Chem. 2014;86(14):6931-9.

34. Xuan Y, Scheuermann EB, Meda AR, Hayen H, von Wirén N, Weber G. Separation and identification of phytosiderophores and their metal complexes in plants by zwitterionic hydrophilic interaction liquid chromatography coupled to electrospray ionization mass spectrometry. J Chromatogr A. 2006;1136(1):73-81.

35. Petritis KN, Chaimbault P, Elfakir C, Dreux M. Ion-pair reversedphase liquid chromatography for determination of polar underivatized amino acids using perfluorinated carboxylic acids as ion pairing agent. 
J Chromatogr A. 1999;833(2):147-55.

36. Chaimbault P, Petritis K, Elfakir C, Dreux M. Determination of 20 underivatized proteinic amino acids by ion-pairing chromatography and pneumatically assisted electrospray mass spectrometry. J Chromatogr A. 1999;855(1):191-202.

37. de Person M, Sevestre A, Chaimbault P, Perrot L, Duchiron F, Elfakir C. Characterization of low-molecular weight peptides in champagne wine by liquid chromatography/tandem mass spectrometry. Anal Chim Acta. 2004;520(1-2):149-58.

38. Canabady-Rochelle LLS, Harscoat-Schiavo C, Kessler V, Aymes A, Fournier F, Girardet J-M. Determination of reducing power and metal chelating ability of antioxidant peptides: revisited methods. Food Chem. 2015;183:129-35.

39. Zhao J, Posa DK, Kumar V, Hoetker D, Kumar A, Ganesan S, et al. Carnosine protects cardiac myocytes against lipid peroxidation products. Amino Acids. 2019;51(1):123-38.

40. Lagarrigue M, Bossée A, Afonso C, Fournier F, Bellier B, Tabet J-C. Diastereomeric differentiation of peptides with CuII and FeII complexation in an ion trap mass spectrometer. J Mass Spectrom. 2006;41(8):1073-85.

41. Yamauchi O, Odani A, Takani M. Metal-amino acid chemistry. Weak interactions and related functions of side chain groups. Dalton Trans. 2002;18:3411-21.

42. de Person M, Chaimbault P, Elfakir C. Analysis of native amino acids by liquid chromatography/electrospray ionization mass spectrometry: comparative study between two sources and interfaces. J Mass Spectrom. 2008;43(2):204-15.

43. Sóvágó I, Várnagy K, Lihi N, Grenács Á. Coordinating properties of peptides containing histidyl residues. Coord Chem Rev. 
$2016 ; 327-328: 43-54$.

44. Pearson RG. Hard and soft acids and bases. Surv Prog Chem. 1969;5:1-51.

45. Sóvágó I, Ösz K. Metal ion selectivity of oligopeptides. Dalton Trans. 2006;32:3841-54.

46. de la Hoz L, Ponezi AN, Milani RF, Nunes da Silva VS, Sonia de Souza A, Bertoldo-Pacheco MT. Iron-binding properties of sugar cane yeast peptides. Food Chem. 2014;142:166-9. 